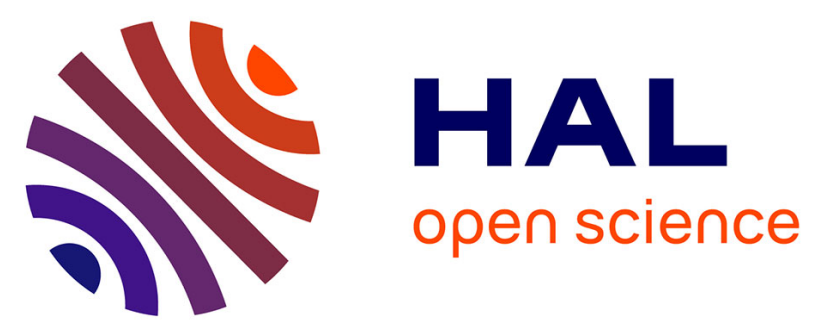

\title{
Tetrameric Lanthanide-Substituted Silicotungstate Ln 8 Si 4 W 40 Nanoclusters: Synthesis, Structural Characterization, Electrochemistry, and Catalytic Application for Oxidation of Thioethers
}

Imran Khan, Vivek Das, Anne-Lucie Teillout, I.M. Mbomekalle, Pedro de

Oliveira, Subash Chandra Sahoo, Firasat Hussain

\section{To cite this version:}

Imran Khan, Vivek Das, Anne-Lucie Teillout, I.M. Mbomekalle, Pedro de Oliveira, et al.. Tetrameric Lanthanide-Substituted Silicotungstate Ln 8 Si 4 W 40 Nanoclusters: Synthesis, Structural Characterization, Electrochemistry, and Catalytic Application for Oxidation of Thioethers. European Journal of Inorganic Chemistry, 2021, 2021 (11), pp.1071-1081. 10.1002/ejic.202001096 hal-03450093

\section{HAL Id: hal-03450093 https://hal.science/hal-03450093}

Submitted on 26 Nov 2021

HAL is a multi-disciplinary open access archive for the deposit and dissemination of scientific research documents, whether they are published or not. The documents may come from teaching and research institutions in France or abroad, or from public or private research centers.
L'archive ouverte pluridisciplinaire HAL, est destinée au dépôt et à la diffusion de documents scientifiques de niveau recherche, publiés ou non, émanant des établissements d'enseignement et de recherche français ou étrangers, des laboratoires publics ou privés. 


\title{
Tetrameric Lanthanide-Substituted Silicotungstate $\left\{\mathrm{Ln}_{8} \mathrm{Si}_{4} \mathrm{~W}_{40}\right\}$ Nanoclusters: Syntheses, Structural Characterization, Electrochemistry and Catalytic Application for Oxidation of
} Thioethers

\author{
Imran Khan, ${ }^{[a]}$ Vivek Das, ${ }^{[a]}$ Anne-Lucie Teillout, ${ }^{[b]}$ Israël-Martyr Mbomekallé, ${ }^{[b]}$ Pedro de Oliveira, ${ }^{[b]}$ \\ Subash Chandra Sahoo, ${ }^{[\mathrm{c}]}$ and Firasat Hussain*[a]
}

Dedication ((optional))

[a] Mr. Imran Khan, Mr. Vivek Das, Dr. Firasat Hussain

Department of Chemistry

University of Delhi, Faculty of Science, North Campus, Delhi-110007, India

E-mail: fhussain@chemistry.du.ac.in

[b] Ms. Anne-Lucie Teillout, Dr. Israël-Martyr Mbomekallé, Prof. Pedro de Oliveira Institut de Chimie Physique, UMR 8000 CNRS, Bâtiment 350, Faculté des Sciences d'Orsay,

Université Paris-Saclay, 91405 Orsay Cedex - France

[c] Dr. Subash Chandra Sahoo

Department of Chemistry \& Center of Advanced Studies in Chemistry

Panjab University, Chandigarh-160014, India.

Supporting information for this article is given via a link at the end of the document.

\begin{abstract}
All the title nanoclusters 1-10 with the molecular formula $\left[\left(\mathrm{Ln}_{2} \mathrm{SiW}_{10} \mathrm{O}_{38}\right)_{4}\left(\mathrm{~W}_{3} \mathrm{O}_{8}\right)(\mathrm{OH})_{4}\left(\mathrm{H}_{2} \mathrm{O}\right)_{2}\right]^{26-}\left[\mathrm{Ln}^{\prime \prime \prime}=\mathrm{Sm}(\mathbf{1}), \mathrm{Eu}(\mathbf{2}), \mathrm{Gd}(\mathbf{3})\right.$, $\mathrm{Tb}$ (4), Dy (5), Ho (6), $\operatorname{Er}(7), \operatorname{Tm}(8), \mathrm{Yb}(9)$, and $\mathrm{Y}(10)]$ have been synthesized and isolated as mixed sodium and potassium salts. These nanoclusters are characterized by various analytical techniques such as FT-IR, UV/Vis, Photoluminescence, Single crystal X-ray diffraction, Electrochemistry, ICP-AES and Thermogravimetric analysis, and Powder X-ray diffraction. The $\left\{\mathrm{Ln}_{8} \mathrm{Si}_{4} \mathrm{~W}_{40}\right\}$ complexes show high efficiency and selectivity for the oxidation of thioethers using $\mathrm{H}_{2} \mathrm{O}_{2}$ as green oxidant. It is worth mentioning that the catalyst can be recovered even after five cycles of reaction with only a slight loss in its activity.
\end{abstract}

\section{Introduction}

Polyoxometalates (POMs) are metal-oxygen nanoclusters that consist of early transition metals such as Mo (VI), W (VI), and V $(V)$ in their highest oxidation state. Due to the flexibility in their structure, size, charge density, and redox potential, POMs show various interesting applications in many fields like medicine, material science, catalysis, magnetism, clinical chemistry, photochemistry, and analytical chemistry. ${ }^{[1-8]}$ The lacunary POMs can be derived from their parent compounds such as Keggin-type ions $\left[\mathrm{XW}_{12} \mathrm{O}_{40}\right]^{\mathrm{n}-}\left(\mathrm{X}=\mathrm{As}^{\mathrm{v}}, \mathrm{P}^{\mathrm{v}}, \mathrm{Ge}^{\mathrm{IV}}, \mathrm{Si}^{\mathrm{lv}}\right.$, etc. $)$, and these lacunary POMs consist of multiple oxygen donor atoms as well as multiple coordination sites which are more susceptible to construct a variety of structures. It is known that lanthanidecontaining POMs exhibit structural varieties and have impressive properties that are useful in various application fields as mentioned above. A wide range of research papers has been published on lanthanide-substituted lacunary POMs. In the year 1971, Peacock and Weakley reported the synthesis of the first lanthanide-containing polyoxometalates. However, structural characterization evidence was not provided..$^{[9]}$ Pope and coworkers reported a cerium-containing arsenotungstate of molecular formula $\left[\mathrm{Ce}_{16} \mathrm{As}_{2}\left(\mathrm{H}_{2} \mathrm{O}\right)_{36} \mathrm{~W}_{148} \mathrm{O}_{524}\right]^{76-} \cdot{ }^{[10]}$ In 1991, Qu et al. reported the interaction of a monolacunary Keggin-type silicotungstate with early lanthanide ions to form $\left[\operatorname{Ln}\left(\beta_{2-}\right.\right.$ $\left.\left.\mathrm{SiW}_{11} \mathrm{O}_{39}\right)\right]^{13-}$ polyanions ( $\mathrm{Ln}^{\mathrm{III}}=\mathrm{La}, \mathrm{Ce}, \mathrm{Pr}, \mathrm{Nd}, \mathrm{Sm}, \mathrm{Gd}$, and $\mathrm{Er}$ ). However, no structural evidence was provided either. ${ }^{[11]}$ Mialane et al. synthesized the lanthanide-substituted monolacunary Keggin-type silicotungstate polyanions $\left[\mathrm{Ln}\left(\alpha-\mathrm{SiW}_{11} \mathrm{O}_{39}\right)\right]^{8-}\left(\mathrm{Ln}^{\prime \prime \prime}=\right.$ $\mathrm{Yb}, \mathrm{Nd}, \mathrm{Eu}$, and $\mathrm{Gd})$. They found that these isolated compounds were strongly affected by the nature of the lanthanide cations. ${ }^{[12]}$ Gouzerh et al. in 2002, reported a cerium-containing antimonate $\left[\mathrm{Ce}_{3} \mathrm{Sb}_{4} \mathrm{~W}_{2} \mathrm{O}_{8}\left(\mathrm{H}_{2} \mathrm{O}\right)_{10}\left(\mathrm{SbW}_{9} \mathrm{O}_{33}\right)_{4}\right]^{19-}$ and arsenotungstate $\left[\mathrm{Ce}\left(\mathrm{H}_{2} \mathrm{O}\right)_{5} \mathrm{As}_{4} \mathrm{~W}_{40} \mathrm{O}_{140}\right]^{25-}$. ${ }^{[13]} \mathrm{Niu}$ et al. reported a onedimensional (1D) structure with the formula $\mathrm{K}_{3}\left[\left(\operatorname{Pr}\left(\mathrm{H}_{2} \mathrm{O}\right)_{4} \mathrm{SiW}_{11} \mathrm{O}_{39}\right)\left(\mathrm{NaPr}_{2}\left(\mathrm{H}_{2} \mathrm{O}\right)_{12}\right)\left(\operatorname{Pr}\left(\mathrm{H}_{2} \mathrm{O}\right)_{4} \mathrm{SiW}_{11} \mathrm{O}_{39}\right)\right] \cdot 13.5 \mathrm{H}$ ${ }_{2} \mathrm{O} .{ }^{[14]}$ The crystal structure of this complex consists of two distinct units of $\left[\operatorname{Pr}\left(\mathrm{H}_{2} \mathrm{O}\right)_{4} \mathrm{SiW}_{11} \mathrm{O}_{39}\right]^{5-}$ and one $\left[\mathrm{NaPr}_{2}\left(\mathrm{H}_{2} \mathrm{O}\right)_{12}\right]^{7+}$ subunit, that is further linked with the help of praseodymium and sodium cations via bridging and terminal oxygen atoms of the Keggin ion $\left[\alpha-\mathrm{SiW}_{11} \mathrm{O}_{39}\right]^{8-}$, giving rise to a complete onedimensional structure. In 2006, Niu et al. also synthesized 1D and 2D structures of three new organic-inorganic hybrid monolacunary Keggin-type silico and germanotungstate of the formula $\mathrm{H}\left\{\left[\mathrm{Sm}\left(\mathrm{H}_{2} \mathrm{O}\right)_{5.5}(\mathrm{DMF})_{0.5}\right]_{2}\left[\mathrm{Sm}\left(\mathrm{H}_{2} \mathrm{O}\right)_{2}(\mathrm{DMF})\right]\left[\mathrm{Sm}\left(\mathrm{H}_{2} \mathrm{O}\right)_{3}(\alpha-\right.\right.$ $\left.\left.\left.\mathrm{SiW}_{11} \mathrm{O}_{39}\right)\right]_{2}\right\}, \quad\left[\mathrm{Sm}\left(\mathrm{H}_{2} \mathrm{O}\right)_{6}\right]_{0.25}\left[\mathrm{Sm}\left(\mathrm{H}_{2} \mathrm{O}\right)_{5}\right]_{0.25} \mathrm{H}_{0.5}\left\{\mathrm{Sm}\left(\mathrm{H}_{2} \mathrm{O}\right)_{7^{-}}\right.$ $\left.\left[\mathrm{Sm}\left(\mathrm{H}_{2} \mathrm{O}\right)_{2}(\mathrm{DMSO})\left(\alpha-\mathrm{SiW}_{11} \mathrm{O}_{39}\right)\right]\right\} \cdot 45 \mathrm{H}_{2} \mathrm{O}$, and $\left[\mathrm{Dy}\left(\mathrm{H}_{2} \mathrm{O}\right)_{4}\right]_{0.25}\left[\mathrm{Dy}\left(\mathrm{H}_{2} \mathrm{O}\right)_{6}\right]_{0.25} \mathrm{H}_{0.5}\left\{\mathrm{Dy}\left(\mathrm{H}_{2} \mathrm{O}\right)_{7}\left[\mathrm{Dy}\left(\mathrm{H}_{2} \mathrm{O}\right)_{2}(\mathrm{DMSO})(\alpha-\right.\right.$ $\left.\left.\left.\mathrm{GeW}_{11} \mathrm{O}_{39}\right)\right]\right\} \cdot 25 \mathrm{H}_{2} \mathrm{O} .{ }^{[15]}$ All three compounds show good thermal stability and magnetic properties. In 2007, Kortz et al. have reported twenty cerium-containing germanotungstates of the formula $\left[\mathrm{Ce}_{20} \mathrm{Ge}_{10} \mathrm{~W}_{100} \mathrm{O}_{376}(\mathrm{OH})_{4}\left(\mathrm{H}_{2} \mathrm{O}\right)_{36}\right]^{56-}{ }^{516]}$ Patzke et al. isolated three new lanthanide-substituted silicotungstates based on open Wells-Dawson fragments $\left[\mathrm{Ln}_{2}\left(\mathrm{H}_{2} \mathrm{O}\right)_{7} \mathrm{SiW}_{18} \mathrm{O}_{66}\right]^{10-}\left(\mathrm{Ln}^{\prime \prime \prime}=\right.$ $\mathrm{Eu}$, and $\mathrm{Tb}$ ) and a sandwich-type monolacunary Keggin-type $\left[\mathrm{Eu}\left(\alpha-\mathrm{SiW}_{11} \mathrm{O}_{39}\right)_{2}\right]^{13-}$ polyanion. ${ }^{[17]}$ In 2008 , Khoshnavazi et al. have reported a sandwich-type carbonate encapsulated samarium-containing silicotungstate of the formula $[(\beta-$ 
$\left.\left.\mathrm{SiW}_{9} \mathrm{O}_{34}\right)_{2}\left(\mathrm{H}_{2} \mathrm{OSm}\right)_{3} \mathrm{CO}_{3}\right]^{13-}$, which consists of a planar triad of three lanthanide ions. Further, they also synthesized samariumcontaining arseno and germanotungstate analogs; [ $\alpha-$ $\left.\left.\mathrm{AsW}_{9} \mathrm{O}_{34}\right)_{2}\left(\mathrm{H}_{2} \mathrm{OSm}\right)_{3} \mathrm{CO}_{3}\right]^{11-}$ and $\left[\left(\beta-\mathrm{GeW}_{9} \mathrm{O}_{34}\right)_{2}\left(\mathrm{H}_{2} \mathrm{OSm}\right)_{3} \mathrm{CO}_{3}\right]^{13-}$, respectively. ${ }^{[18-20]} \mathrm{A}$ new class of lanthanide-containing phosphotungstates $\left[\left(\mathrm{PLn}_{2} \mathrm{~W}_{10} \mathrm{O}_{38}\right)_{4}\left(\mathrm{~W}_{3} \mathrm{O}_{14}\right)\right]^{30-}\left(\mathrm{Ln}^{\mathrm{III}}=\mathrm{Y}\right.$, and $\left.\mathrm{Eu}\right)$ was reported by Francesconi and co-workers. ${ }^{[21]}$ Later, Khoshnavazi's group showed that in aqueous solution, the carbonate encapsulated samarium-containing sandwich-type $\left[\left(\alpha-\mathrm{SiW}_{9} \mathrm{O}_{34}\right)_{2}\left(\mathrm{H}_{2} \mathrm{OSm}\right)_{3} \mathrm{CO}_{3}\right]^{13-}$ complex convert into a new class of rare-earth metal-substituted polyoxometalate of the formula $\left.\left[\left(\mathrm{SiW}_{10} \mathrm{Sm}_{2} \mathrm{O}_{38}\right)_{4}\left(\mathrm{~W}_{3} \mathrm{O}_{8}(\mathrm{OH})_{4}\right)\left(\mathrm{H}_{2} \mathrm{O}\right)_{2}\right)\right]^{26-}$. ${ }^{[22]}$ In 2014 , Hussain et al. have reported a series of lanthanide-containing phosphotungstates which resembles a similar structure reported by Francesconi. The structural formula of the complex is $\left[\left(\mathrm{Ln}_{2} \mathrm{PW}_{10} \mathrm{O}_{38}\right)_{4}\left(\mathrm{~W}_{3} \mathrm{O}_{8}\right)(\mathrm{OH})_{4}\left(\mathrm{H}_{2} \mathrm{O}\right)_{2}\right]^{26-}\left(\mathrm{Ln}^{\mathrm{III}}=\mathrm{Sm}, \mathrm{Eu}, \mathrm{Gd}, \mathrm{Tb}, \mathrm{Dy}\right.$, $\mathrm{Ho}, \mathrm{Er}, \mathrm{Tm}, \mathrm{Yb}$, and $\mathrm{Y}) .{ }^{[23]}$ Thereafter, germanotungstate analogs were reported by Hussain et al. in 2019. ${ }^{24]}$ In addition with POMs, recently many other coordination complexes were also reported for its applications in the field of catalysis and

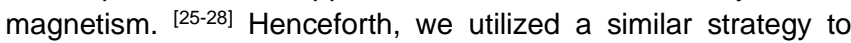
obtain such isostructural lanthanide-substituted POMs by using a trilacunary Keggin-type $\mathrm{Na}_{10}\left[\mathrm{~A}-\alpha-\mathrm{SiW}_{9} \mathrm{O}_{34}\right] \cdot 16 \mathrm{H}_{2} \mathrm{O}$ precursor. We have changed the reaction parameters and optimized the reaction conditions to isolate a series of ten lanthanidesubstituted silicotungstates of the formula $\left[\left(\mathrm{Ln}_{2} \mathrm{SiW}_{10} \mathrm{O}_{38}\right)_{4}\left(\mathrm{~W}_{3} \mathrm{O}_{8}\right)(\mathrm{OH})_{4}\left(\mathrm{H}_{2} \mathrm{O}\right)_{2}\right]^{26-}\left[\mathrm{Ln}^{\prime \prime \prime}=\mathrm{Sm}(\mathbf{1}), \mathrm{Eu}(\mathbf{2}), \mathrm{Gd}\right.$ (3), Tb (4), Dy (5), Ho (6), $\operatorname{Er}$ (7), $\operatorname{Tm}$ (8), Yb (9), Y (10)]. Although Khosnavazi's group have reported the Sm complex, it was obtained as a by-product. The complexes reported here are obtained as a major product by employing a simple one-pot procedure under mild reaction conditions. We have investigated the photoluminescence property of complexes and are observed only in the case of the Sm, Eu, and Dy complexes. Moreover, we have also investigated the catalytic applications for the oxidation of thioethers. The screening of all the catalysts is performed under optimized conditions. However, we have selected $\left\{\mathrm{Dy}_{8} \mathrm{Si}_{4} \mathrm{~W}_{40}\right\}$ POM as the model catalyst and checked for the substrate scope only due to the high yield of this complex. Furthermore, due to the redox properties of POMs, electrochemistry of the synthesized complexes was carried out.

\section{Results and Discussion}

During the syntheses of compounds $\mathbf{1 a}-\mathbf{1 0 a}$, several prerequisite parameters such as $\mathrm{pH}$, concentration of the solution, reaction temperature and time have to be taken care of. Herein, we have used $0.2 \mathrm{mmol}$ of trilacunary Keggin-type $\mathrm{Na}_{10}[\alpha-$ $\left.\mathrm{SiW}_{9} \mathrm{O}_{34}\right] \cdot 16 \mathrm{H}_{2} \mathrm{O}$ precursor and reacted with $0.1 \mathrm{mmol}$ of lanthanide nitrate salt in $0.25 \mathrm{M}$ aqueous $\mathrm{KCl}$ solution. The reaction has been carried out at $80{ }^{\circ} \mathrm{C}$ for $1 \mathrm{~h}$. The $\mathrm{pH}$ of the reaction mixture is found to be around 4.5. At this $\mathrm{pH}$, the trilacunary Keggin-type $\left[\alpha-\mathrm{SiW}_{9} \mathrm{O}_{34}\right]^{10-}$ anion easily transforms to the dilacunary Keggin-type $\left[\alpha-\mathrm{SiW}_{10} \mathrm{O}_{36}\right]^{8-}$ ion. Colorless blockshaped crystals were isolated after two-three days. The isolated crystals were salt of mixed potassium and sodium with the formula $\mathrm{K}_{11} \mathrm{Na}_{15}\left[\left(\mathrm{Ln}_{2} \mathrm{SiW}_{10} \mathrm{O}_{38}\right)_{4}\left(\mathrm{~W}_{3} \mathrm{O}_{8}\right)(\mathrm{OH})_{4}\left(\mathrm{H}_{2} \mathrm{O}\right)_{2}\right]\left[\mathrm{Ln}^{\text {III }}=\mathrm{Sm}\right.$ (1a), Eu (2a), Gd (3a), Tb (4a), Dy (5a), Ho (6a), Er (7a), Tm (8a), $\mathrm{Yb}(\mathbf{9 a}), \mathrm{Y}(\mathbf{1 0 a})]$. Later, all the polyanions were characterized by various analytical techniques such as FT-IR, UV/Vis, TGA and
SC-XRD. These polyanions were further investigated for different applications such as in Catalysis, Photoluminescence, and Electrochemistry.

\section{Structure of the polyanion}

Herein, we have reported the synthesis of lanthanide-substituted silicotungstates, which are stable both in the solid-state as well as in an aqueous solution. All the compounds are structurally characterized by single crystal X-ray diffraction analysis which reveals that the nanoclusters are isostructural and crystallize in the monoclinic crystal system having space group $P-1$. The complexes 1a-10a consist of four $\left[\mathrm{SiW}_{10} \mathrm{O}_{36}\right]^{8-}$ anions, eight $\mathrm{Ln}^{3+}$ cations, and seven extra tungsten atoms, which form a $\left[\mathrm{Ln}_{8} \mathrm{~W}_{7} \mathrm{O}_{30}\right]^{6+}$ network. The complexes are formed by four $\left[\mathrm{SiW}_{10} \mathrm{O}_{36}\right]^{8-}$ anions connected by a network of $\mathrm{Ln}-\mathrm{O}$ bonds. Eight lanthanide ions and seven additional tungsten atoms in $\left[\mathrm{Ln}_{8} \mathrm{~W}_{7} \mathrm{O}_{30}\right]^{6+}$ network connected to the $\left[\mathrm{SiW}_{10} \mathrm{O}_{36}\right]^{8-}$ give rise to a complete tetrameric $\left[\left(\mathrm{Ln}_{2} \mathrm{SiW}_{10} \mathrm{O}_{38}\right)_{4}\left(\mathrm{~W}_{3} \mathrm{O}_{8}\right)(\mathrm{OH})_{4}\left(\mathrm{H}_{2} \mathrm{O}\right)_{2}\right]^{26-}$ structure (Figure 1).

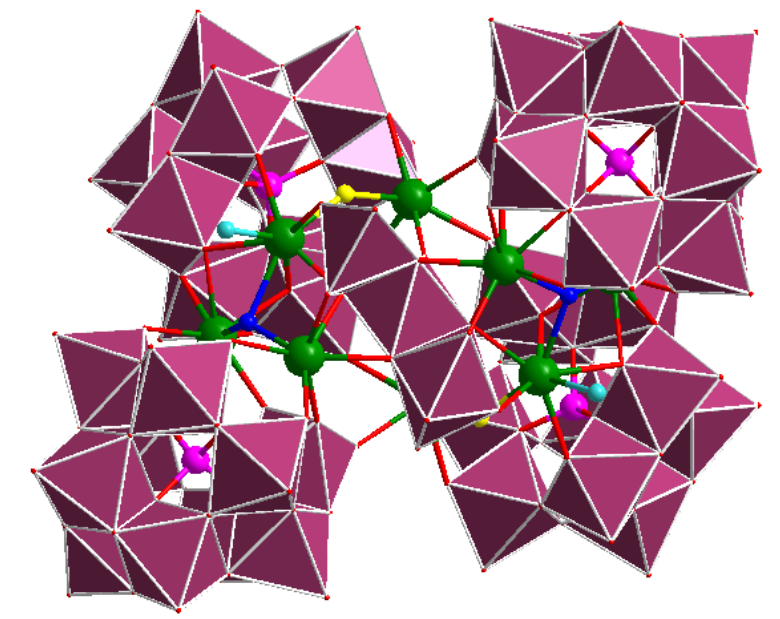

Figure 1. Polyhedral representation of the complex 1a-10a. (Color code: dark green: lanthanide; pink: silicon; dark blue: $\mu_{3}-\mathrm{OH}$; yellow: $\mu_{2}-\mathrm{OH}$; aqua: terminal water molecule; plum: polyhedra).

If the extra tungsten unit is removed from the structure, then it can be seen as an assembly of two asymmetric units. Each asymmetric unit consists of four lanthanide ions and two distorted Keggin-type $\left[\mathrm{SiW}_{10} \mathrm{O}_{36}\right]^{8-}$ units. Each of the $\left[\mathrm{SiW}_{10} \mathrm{O}_{36}\right]^{8-}$ asymmetric units are substituted with two lanthanide ions (Figure 2) and these lanthanide ions are connected to Keggin-type ions via Ln-O linkages. The selected bond lengths and bond angles for Ln-O linkages are shown in Table S1 and Table S2 respectively. Bond Valence Sum (BVS) calculations were also performed for all the oxygen atoms to find out what sort of ligand they are: oxo, hydroxo or water molecules. The BVS values for the oxygen atoms bridging between lanthanide ions are found within the range of 0.95 to 1.25 . This indicates that the oxygen atoms labeled as $\mathrm{O} 73$ and $\mathrm{O} 112$ are $\mu_{2^{-}}$and $\mu_{3^{-}}$hydroxo linkages respectively. ${ }^{[29]}$ For the terminal oxygen atom $\mathrm{O} 162$, the BVS value is found in the range of 0.25 0.36 , suggesting it to be a water molecule. The BVS values for oxygen atoms bridging between lanthanide and tungsten atoms are found to be in the range of 1.506-1.707, which suggests that 
they are oxo linkages. Henceforth, according to BVS values the polyanion has an overall charge of -26 , which is compensated with sodium and potassium cations.
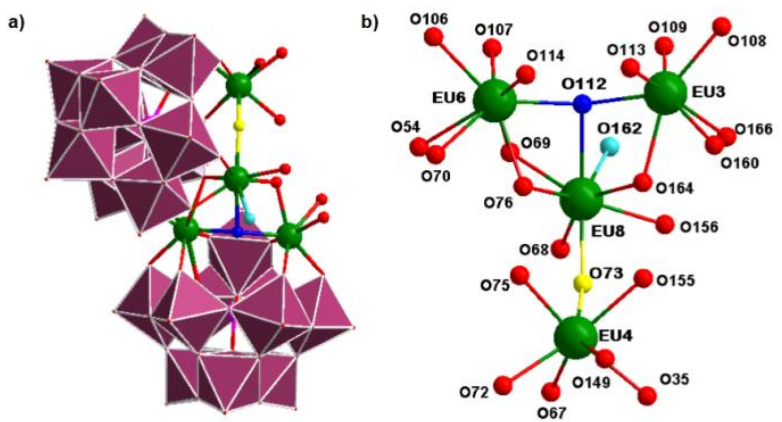

Figure 2. a) Asymmetric unit consists of two distorted Keggin-type parts $\left[\mathrm{Eu}_{2} \mathrm{SiW}_{10} \mathrm{O}_{38}\right]^{6-}$ connected to each other by $\mathrm{Eu}-\mathrm{O}$ bonds; b) Coordination environment of lanthanide ions (Color code: dark green: lanthanide; pink: silicon; dark blue: $\mu_{3}-\mathrm{OH}$; yellow: $\mu_{2}-\mathrm{OH}$; aqua: terminal water molecule; plum: polyhedra).

The lanthanides Eu3 and Eu4 are seven-coordinated with a capped Trigonal prismatic geometry, and the coordination sites of Eu3 are occupied by one $\mu_{3}-\mathrm{OH}$ hydroxo and six oxygen atoms connected to the parent Keggin ion. The coordination sphere of Eu4 is occupied by one $\mu_{2}-\mathrm{OH}$ and six oxygen atoms of the Keggin ion. Eu6 and Eu8 are eight-coordinated having a Square-antiprismatic geometry, and the coordination sphere of Eu8 is fulfilled with one $\mu_{3}-\mathrm{OH}$, one terminal water molecule, and six neighboring oxygen atoms from tungsten polyhedra. Eu6 is linked with one $\mu_{3}-\mathrm{OH}$ and seven oxygen atoms from tungsten polyhedra.

\section{Catalysis}

The catalytic oxidations of organic compounds by using mild conditions have both a potential utility and wide-spread interest. The selective oxidation of thioether compounds is interesting due to the versatile application of their oxidized sulfone $\left(\mathrm{RSO}_{2} \mathrm{R}^{\prime}\right)$ and sulfoxide (RSOR') forms in various fields such as sulfoxidation reactions, oxido-transfer reagents, biochemistry, chemical industry, and medicinal chemistry. ${ }^{[30-32]} \mathrm{H}_{2} \mathrm{O}_{2}$ has been used as an oxidant in the reaction and is also known as a "green" oxidant, as the side product of the $\mathrm{H}_{2} \mathrm{O}_{2}$ oxidation reaction is water. Polyoxometalates have been investigated as catalysts due to their versatile features such as redox properties, protontransfer reactions, and structural variety. Here, we have utilized POM complexes as catalysts for the oxidation reaction of a standard substrate like biphenyl sulfide in the presence of $\mathrm{H}_{2} \mathrm{O}_{2}$ as the oxidant. We have investigated the catalytic behavior of the lanthanide-substituted silicotungstates $\left\{\mathrm{Dy}_{8} \mathrm{Si}_{4} \mathrm{~W}_{40}\right\}$ and observed that all the complexes show excellent catalytic activity (Table S4). Further, for the catalytic reactions, we have taken $\left\{\mathrm{Dy}_{8} \mathrm{Si}_{4} \mathrm{~W}_{40}\right\}$ as the model catalyst due to its high yield during the synthesis. The selectivity and conversion to sulfoxide (RSOR') and sulfone $\left(\mathrm{RSO}_{2} \mathrm{R}^{\prime}\right)$ were investigated by Gas Chromatography using the internal standard method (GC spectra Figure S12). Initially, biphenyl sulfide has been used as a standard substrate, which is oxidized into biphenyl sulfoxide (PhSOPh) and biphenyl sulfone $\left(\mathrm{PhSO}_{2} \mathrm{Ph}\right)$.

Table 1. Oxidation of biphenyl sulfide by using catalyst $\left\{\mathrm{Dy}_{8} \mathrm{Si}_{4} \mathrm{~W}_{40}\right\}^{[\mathrm{a}]}$

\begin{tabular}{|c|c|c|c|c|c|c|c|}
\hline \multirow{2}{*}{$\begin{array}{c}\text { Entr } \\
y\end{array}$} & \multirow{2}{*}{$\begin{array}{c}\text { Temperature } \\
\left({ }^{\circ} \mathrm{C}\right)\end{array}$} & \multirow{2}{*}{$\begin{array}{c}\mathrm{H}_{2} \mathrm{O}_{2} \\
(\mathrm{mmol})\end{array}$} & \multirow{2}{*}{$\begin{array}{l}\text { Catalyst } \\
\text { loading } \\
\text { (mol \%) }\end{array}$} & \multirow{2}{*}{$\begin{array}{l}\text { Convers } \\
\text { ion }(\%)^{[b]}\end{array}$} & \multicolumn{2}{|c|}{ Selectivity $(\%)^{[c]}$} & \multirow{2}{*}{$\begin{array}{l}\text { Tim } \\
\text { (Min }\end{array}$} \\
\hline & & & & & (PhSOPh & $\mathrm{PhSO}_{2} \mathrm{Ph}$ ) & \\
\hline 1 & 50 & 4 & 0.14 & 90 & 20 & 80 & 40 \\
\hline 2 & 50 & 4 & 0.20 & 99 & 5 & 95 & 40 \\
\hline 3 & 50 & 4 & 0.27 & 100 & 0 & 100 & 40 \\
\hline 4 & 40 & 4 & 0.27 & 100 & 25 & 75 & 40 \\
\hline 5 & 25 (RT) & 4 & 0.27 & 30 & 70 & 30 & 40 \\
\hline 6 & 50 & 0 & 0.27 & 10 & 80 & 20 & 40 \\
\hline 7 & 50 & 4 & 0.27 & 100 & 44 & 56 & 30 \\
\hline
\end{tabular}

[a] Reaction conditions: biphenyl sulfide 0.5 mmol, oxidant $\mathrm{H}_{2} \mathrm{O}_{2}(30 \%$ aqueous), $0-4 \mathrm{mmol}$, catalyst $\left\{\mathrm{Dy}_{8} \mathrm{Si}_{4} \mathrm{~W}_{40}\right\}$ loading $0.14-0.27 \mathrm{~mol} \%$, temperature $30-50{ }^{\circ} \mathrm{C}, 40 \mathrm{~min}$, acetonitrile $1 \mathrm{~mL}$. [b] Conversion based on substrate consumption and determined by GC-FID using an internal standard technique. [c] The Selectivity ( $\mathrm{PhSOPh} / \mathrm{PhSO}{ }_{2} \mathrm{Ph}$ ) is determined by $\mathrm{GC}$.

It was observed that the substrate was completely consumed in 40 min and produced $\mathrm{PhSO}_{2} \mathrm{Ph}$, with $100 \%$ selectivity at $50{ }^{\circ} \mathrm{C}$ in $1 \mathrm{~mL}$ of acetonitrile, $0.27 \mathrm{~mol} \%$ of the catalyst $\left\{\mathrm{Dy}_{8} \mathrm{Si}_{4} \mathrm{~W}_{40}\right\}$ and $4 \mathrm{mmol}$ of $\mathrm{H}_{2} \mathrm{O}_{2}$. We have also oxidized various thioethers to the corresponding oxygenated products by using $\mathrm{H}_{2} \mathrm{O}_{2}$ and $\left\{\mathrm{Dy}_{8} \mathrm{Si}_{4} \mathrm{~W}_{4}{ }_{10}\right\}$ as the catalyst. When the reaction is carried out in the absence of a catalyst (Table S5, Entry 3), the conversion is only about $20 \%$ and the selectivity of the major product $\left(\mathrm{PhSO}_{2} \mathrm{Ph}\right)$ is also very low. However, as the catalyst amount is varied from $0.14-0.27 \mathrm{~mol} \%$, we obtain its optimized amount to be $0.27 \mathrm{~mol} \%$, with $100 \%$ selectivity of sulfone (Table 1, Entry $3)$. Under the same conditions, we have also investigated the catalytic activity of the lanthanide salt $\mathrm{Dy}\left(\mathrm{NO}_{3}\right)_{3} \cdot \mathrm{xH}_{2} \mathrm{O}$ and the trilacunary POM precursor $\mathrm{Na}_{10}\left[\mathrm{~A}-\alpha-\mathrm{SiW}_{9} \mathrm{O}_{34}\right] \cdot 16 \mathrm{H}_{2} \mathrm{O}$ in the absence of any catalyst, and the selectivity is found to be $34 \%$ and $98 \%$ respectively (Table S3, Entries 4 and 5). It can be observed that the silicotungstate $\mathrm{Na}_{10}\left[\mathrm{~A}-\alpha-\mathrm{SiW}_{9} \mathrm{O}_{34}\right] \cdot 16 \mathrm{H}_{2} \mathrm{O}$ precursor also shows good catalytic activity, but the amount of this precursor used is very high $(1.08 \mathrm{~mol} \%)$, and the selectivity towards the sulfone decreases upon decreasing the $\mathrm{mol} \%$ of the precursor. Thereafter, we have performed the oxidation reaction in the absence of $\mathrm{H}_{2} \mathrm{O}_{2}$, which results in less conversion to the desired product (Table 1, Entry 6). The small conversion of sulfone and sulfoxide was obtained due to the oxidation in presence of atmospheric oxygen. ${ }^{[33]}$ This indicates that the catalyst $\left\{\mathrm{Dy}_{8} \mathrm{Si}_{4} \mathrm{~W}_{40}\right\}$ shows an excellent catalytic property in the presence of $\mathrm{H}_{2} \mathrm{O}_{2}$. Generally, POMs activate $\mathrm{H}_{2} \mathrm{O}_{2}$ by forming peroxy species. The amount of oxidant also plays an important role in the oxidation reaction, since as the oxidant amount increases the selectivity for the desired product sulfone also increases (Table S5). The optimized ratio of substrate and the oxidant is found to be 1:8 (Table S6). The reaction temperature also affects the selectivity of the biphenyl sulfone. At low 
temperature, the selectivity for $\mathrm{PhSO}_{2} \mathrm{Ph}$ is low, but increases with temperature, reaching an optimized value at $50{ }^{\circ} \mathrm{C}$ (Table 1 , Entries 3, 4 and 5). All these parallel experiments indicate that the compound $\left\{\mathrm{Dy}_{8} \mathrm{Si}_{4} \mathrm{~W}_{40}\right\}$ shows an excellent catalytic activity for the oxidation of thioethers.

Table 2. Effect of the solvent on the reaction ${ }^{[a]}$

\begin{tabular}{ccccc}
\hline Entry & Solvent & $\begin{array}{c}\text { Conversion } \\
(\%)^{[\mathrm{b}]}\end{array}$ & $\begin{array}{c}\text { Selectivity (\%) } \\
\text { PhSOPh }\end{array}$ & PhSO $_{2}$ Ph \\
\hline $\mathbf{1}$ & DMF & 50 & 84 & 16 \\
$\mathbf{2}$ & Toluene & 14 & 57 & 43 \\
$\mathbf{3}$ & $\mathrm{H}_{2} \mathrm{O}$ & 52 & 78 & 22 \\
$\mathbf{4}$ & Acetonitrile & 100 & 0 & 100 \\
$\mathbf{5}$ & Acetonitrile + & 50 & 20 & 80 \\
& $\mathrm{H}_{2} \mathrm{O}(50: 50)$ & & & \\
\hline
\end{tabular}

[a] Reaction conditions: Substrate biphenyl sulfide $0.5 \mathrm{mmol}$, oxidant $\mathrm{H}_{2} \mathrm{O}_{2}$ ( $30 \%$ aqueous), $4 \mathrm{mmol}$, catalyst $0.27 \mathrm{~mol} \%$, temperature $50{ }^{\circ} \mathrm{C}, 40 \mathrm{~min}$ solvent $1 \mathrm{~mL}$. [b] Conversion based on substrate consumption and determined by GC-FID using an internal standard technique. [c] The Selectivity (PhSOPh/ $\mathrm{PhSO}_{2} \mathrm{Ph}$ ) is determined by $\mathrm{GC}$.

We have also checked the catalytic performance in various solvents and it is observed that the selectivity and the conversion of the oxidation reaction are more pronounced in polar solvents as compared to non-polar ones (Table 2). Generally, this happens due to the poor solubility of the catalyst in non-polar solvents. The oxidation reaction has also been carried out in water as a green solvent, but since sulfur alkyl and aryl thioethers are not soluble in water, the catalysis reaction is not much effective. In addition, under the optimized reaction conditions, we have performed the catalysis reaction of different aromatic and alkyl thioethers. Alkyl thioethers are most reactive towards the oxidation into their corresponding sulfone due to the less steric hindrance of the alkyl group, and $100 \%$ selectivity is obtained (Table 3 , entry 9 ). We have also examined that the conversion is still $100 \%$ even on increased steric hindrance, except in the few cases where the selectivity of the sulfone is decreased. Various substituents attached to the aromatic ring also affects the selectivity for the sulfone. The strong electronwithdrawing group-containing substrates, such as 4nitrothianisol and 4-cynothianisol, show less selectivity, as shown in Table 3 (Entries 3 and 6), due to the decrease in the electron density on the benzene ring. The electron-donating group-containing substrates, such as 4-methoxythioanisol and 4methylthioanisol, as shown in Table 3 (Entries 4 and 10), show excellent selectivity which might be due to the high electron density on the sulfur atom in these substrates. We have also studied the oxidation reaction for an aromatic system such as dibenzothiophene, for which an excellent selectivity is obtained as shown in Table 3 (Entry 8). Furthermore, a recycling test was also carried out to evaluate the catalytic performance of the catalyst during the oxidation reaction of the biphenyl sulfide under optimal conditions. A hot filtration experiment was conducted, the catalyst $\left\{\mathrm{Dy}_{8} \mathrm{Si}_{4} \mathrm{~W}_{40}\right\}$ having been removed after 10 minutes by filtration, and the reaction allowed to continue. It was observed that there is a small conversion to the product, suggesting that the reaction mechanism is heterogeneous. In this heterogeneous system, the catalyst was collected by filtration after the completion of the reaction, washed with ethyl acetate, dried, and reused in the next run.
Table 3. Selective oxidation of various alkyl and aryl derivative thioethers by using the catalyst $\left\{\mathrm{Dy}_{8} \mathrm{Si}_{4} \mathrm{~W}_{40}\right\}{ }^{\text {a] }}$

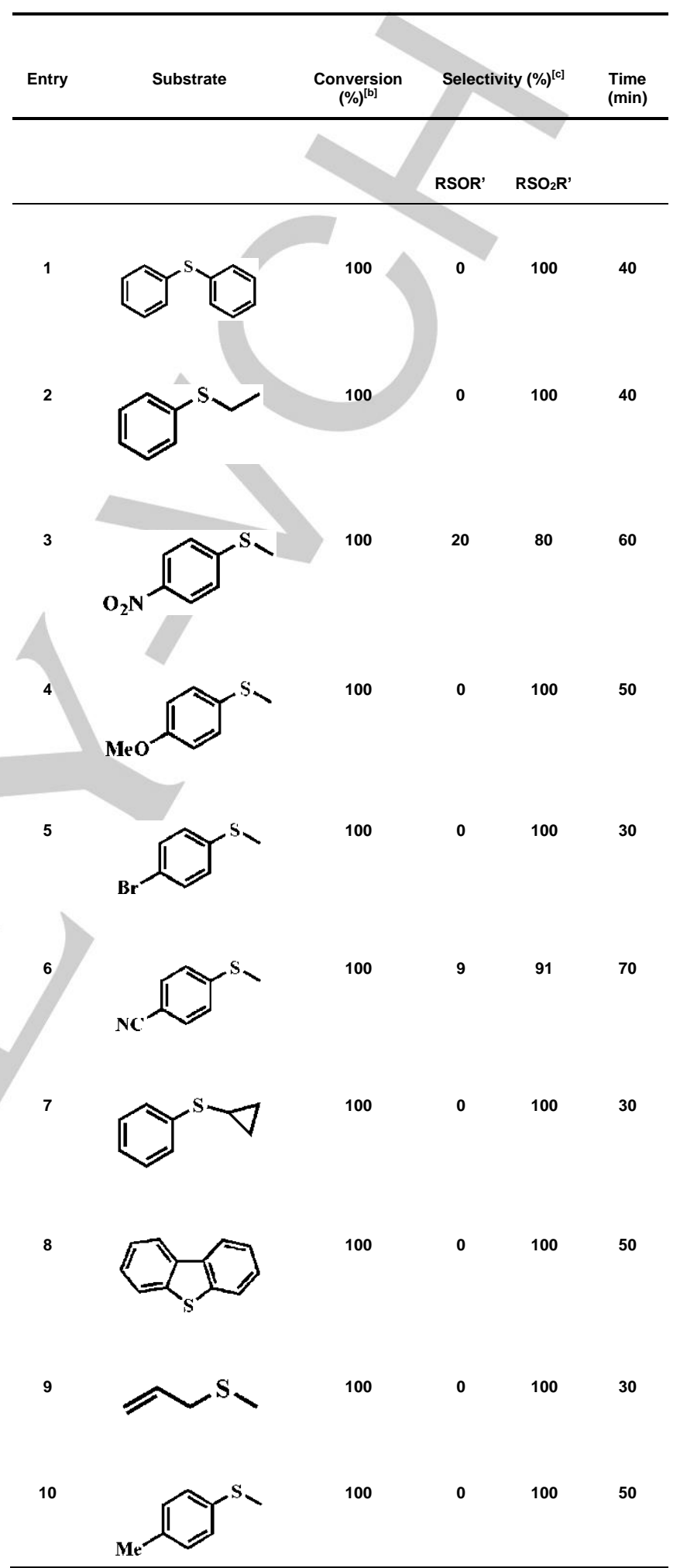

[a] Reaction conditions: Substrate $0.5 \mathrm{mmol}$, oxidant $\mathrm{H}_{2} \mathrm{O}_{2}$ (30\% aqueous), 4 mmol, catalyst $0.27 \mathrm{~mol} \%$, temperature $50{ }^{\circ} \mathrm{C}$, solvent $1 \mathrm{~mL}$. [b] Conversion based on substrate consumption and determined by GC-FID using an internal standard technique. [c] The selectivity (RR'SO/ RR'SO ${ }_{2}$ ) is determined by GC. 
The recycled catalyst can be used up to five consecutive runs, and thereafter the conversion yield and selectivity decrease slightly (Figure 3 ). The recycled catalyst was characterized by FT-IR and it was observed that the FT-IR spectrum was similar to that of the fresh catalyst (Figure S13). The FT-IR spectrum of the recycled catalyst shows major characteristic peaks at around $998 \mathrm{~cm}^{-1}, 931 \mathrm{~cm}^{-1}, 854 \mathrm{~cm}^{-1}, 757 \mathrm{~cm}^{-1}$ and $700 \mathrm{~cm}^{-1}$, similar to the FT-IR spectrum of the fresh catalyst. Hence, this indicates that the catalyst remains stable after five runs.

We have compared our catalyst with some reported results and concluded that $\left\{\mathrm{Dy}_{8} \mathrm{Si}_{4} \mathrm{~W}_{40}\right\}$ shows a better catalytic activity towards the oxidation of thioethers. Notably, our synthesized catalyst requires less time, a smaller amount of solvent, and shows a better selectivity for the sulfone. For instance, the oxidation of biphenyl sulfide (Table 3 , entry 1 ) using $\left\{\mathrm{Dy}_{8} \mathrm{Si}_{4} \mathrm{~W}_{40}\right\}$ as catalyst shows $100 \%$ selectivity for sulfones, and the turnover frequency (TOF) is found to be $517.3 \mathrm{~h}^{-1}$ at $50^{\circ} \mathrm{C}$, which is much higher than some of the reported catalysts. In 2014, Yang et al. reported a catalyst, $\mathrm{Na}_{10} \mathrm{~K}_{22}\left[\mathrm{Zr}_{24} \mathrm{O}_{22}(\mathrm{OH})_{10}\left(\mathrm{H}_{2} \mathrm{O}\right)_{2}\left(\mathrm{~W}_{2} \mathrm{O}_{1} \mathrm{OH}\right)_{2^{-}}\right.$ $\left.\left(\mathrm{GeW}_{9} \mathrm{O}_{34}\right)_{4}\left(\mathrm{GeW}_{8} \mathrm{O}_{31}\right)_{2}\right] \cdot 85 \mathrm{H}_{2} \mathrm{O}$, with a turnover frequency of $22.5 \mathrm{~h}^{-1}$ and a selectivity for biphenyl sulfone of $73 \%$ at $60{ }^{\circ} \mathrm{C} .^{[34]}$ Thereafter, in 2019, they have also reported the $\left(\mathrm{NH}_{4}\right)_{3} \mathrm{Na}_{5} \mathrm{~K}_{6}\left[\mathrm{Zr}_{4}\left(\mu_{3}-\mathrm{O}\right)_{2}(\mu-\mathrm{H})_{2}(\mathrm{ox})_{2}\left(\mathrm{SiW}_{10} \mathrm{O}_{37}\right)_{2}\right] \cdot 23 \mathrm{H}_{2} \mathrm{O}$ catalyst with selectivity for biphenyl sulfone of $42 \%$ and a turnover frequency of $42 \mathrm{~h}^{-1}$ at $60^{\circ} \mathrm{C} .^{[35]}$

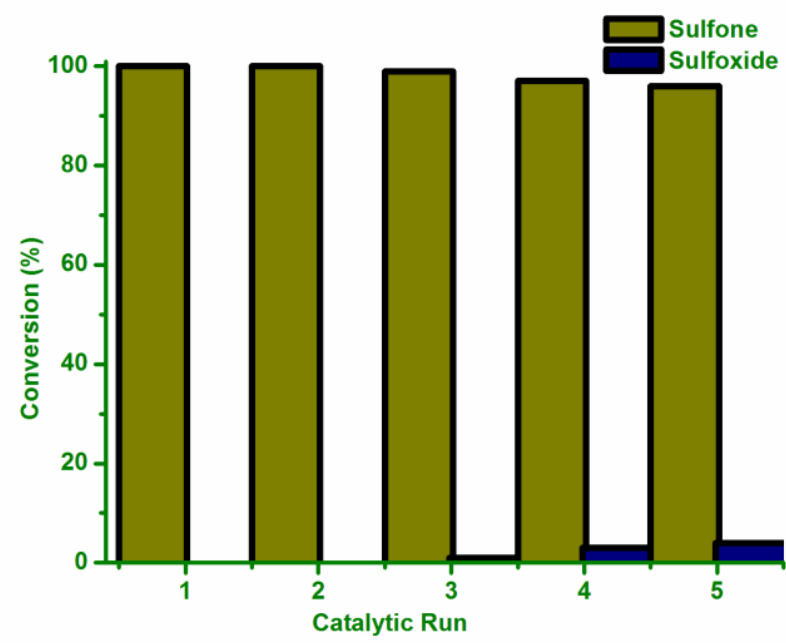

Figure 3. Catalytic runs for the oxidation reaction of thioethers under standard condition.

\section{Electrochemistry}

The electrochemical study of the compounds $1 \mathbf{a}-8 \mathbf{a}$ as well as the lacunary species $\mathrm{Na}_{10}\left[\mathrm{~A}-\alpha-\mathrm{SiW}_{9} \mathrm{O}_{34}\right] \cdot 16 \mathrm{H}_{2} \mathrm{O}$ (ligand) was carried out either in lithium acetate buffer at $\mathrm{pH} 5.0$ and 4.0, or in lithium sulphate buffer at $\mathrm{pH} 3.0$ and 2.0. On the one hand, on a 3 hour time scale and under the present experimental conditions of cyclic voltammetry, the compounds Sm (1a), Eu (2a), Gd (3a), $\mathrm{Tb}(\mathbf{4 a})$, Dy (5a), Er (7a) and $\mathrm{Y}(\mathbf{9 a})$ showed satisfactory stability at $\mathrm{pH} 5.0$ and 3.0. Meanwhile, the compounds $\mathrm{Ho}(\mathbf{6 a}), \mathrm{Tm}(\mathbf{8 a})$ and the ligand had only limited stability over time at $\mathrm{pH} 5.0$ and poor stability at $\mathrm{pH} 3.0$. The voltammogram of the $\mathrm{Na}_{10}[\mathrm{~A}-\alpha$ $\left.\mathrm{SiW}_{9} \mathrm{O}_{34}\right] \cdot 16 \mathrm{H}_{2} \mathrm{O}$ compound (Figure S4) is composed of two reversible waves. The first (noted (a) in Figure S4) is multielectronic and has a shoulder. The latter (noted (\#) in Figure S4) is in the same potential range as the first reduction wave of $\mathrm{SiW}_{11}$ under the same experimental conditions (CV not shown), indicating that the ligand decays and evolves into $\mathrm{SiW}_{11}$. The second reduction wave (noted (b) in Figure S4) seems to indicate a reversible bi-electronic transfer. In addition, a shoulder (noted $\left({ }^{*}\right)$ in Figure S4) is observed in the reverse scan, which is not the case when the potential window is restricted to the study of just the first wave. This observation suggests that a partial degradation of the compound occurs at more negative potentials with the formation of blue derivatives. ${ }^{[36,37]}$ In addition, it should be noted that the stability of this compound over time at $\mathrm{pH} 5.0$ is not marked and its decomposition kinetics increases as the $\mathrm{pH}$ decreases, as expected for a lacunary derivative. Its electrochemical characterisation at $\mathrm{pH}$ below 4.0 was not possible. At $\mathrm{pH} \mathrm{5}$, the study of the peak current as a function of the square root of the scan rate is consistent with a diffusioncontrolled system (Figure S5). The compounds 1a-10a (except Eu (2a)) exhibit a similar electrochemical behaviour in cyclic voltammetry at $\mathrm{pH} 5.0$ (Figure S6) as illustrated in Figure 4.

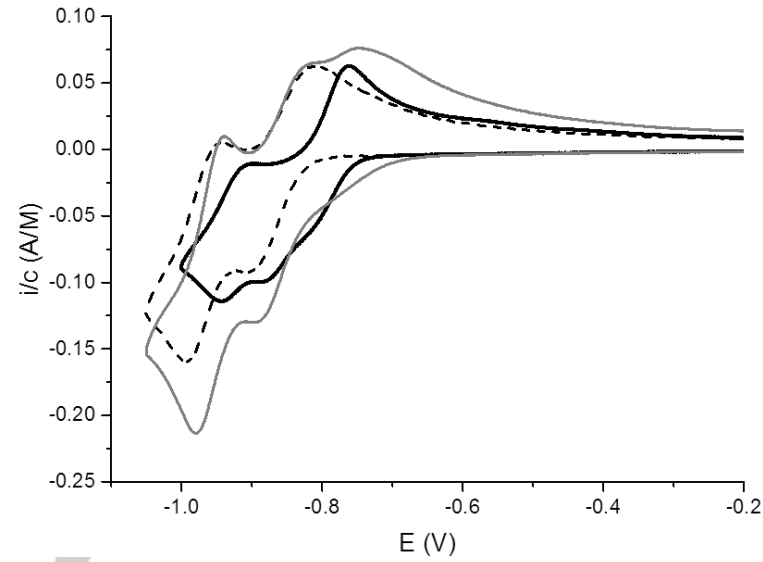

Figure 4. Cyclic voltammograms of $\mathbf{3 a}$ (black and grey lines) and of the ligand (dotted line) recorded in $0.4 \mathrm{M} \mathrm{LiCH}{ }_{3} \mathrm{COO} / \mathrm{CH}_{3} \mathrm{COOH}$ buffer, $\mathrm{pH}=5.0$, at $\mathrm{v}=$ $0.1 \mathrm{~V} / \mathrm{s}$. POM concentrations: [3a] $=0.195 \mathrm{mM}$ and [ligand] $=0.78 \mathrm{mM}$.

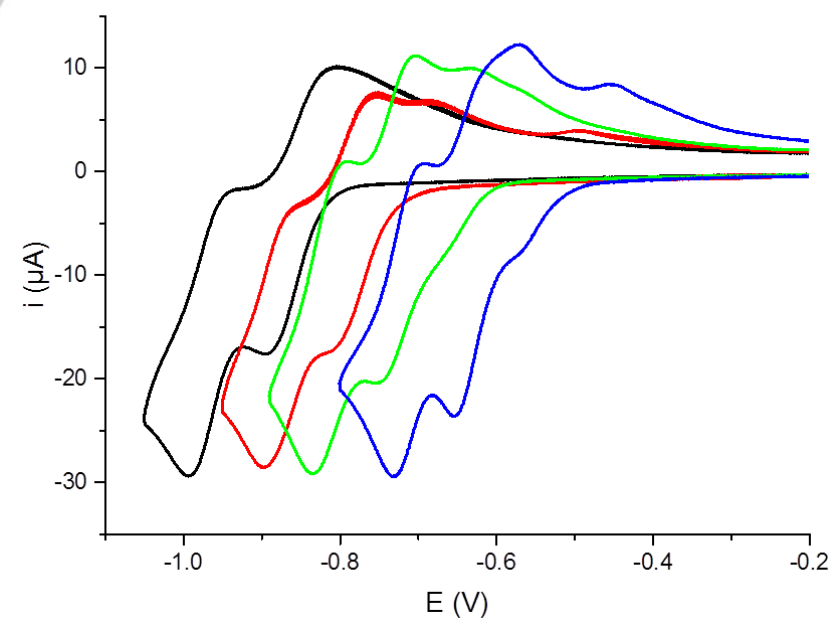

Figure 5. Cyclic voltammograms of $\mathbf{3 a}$ as a function of the $\mathrm{pH}$, recorded in 0.4 $\mathrm{M} \mathrm{LiCH}{ }_{3} \mathrm{COO} / \mathrm{CH}_{3} \mathrm{COOH}$ at $\mathrm{pH}=5.0$ (black) and 4.0 (red), and in $0.2 \mathrm{M}$ $\mathrm{Na}_{2} \mathrm{SO}_{4} / \mathrm{H}_{2} \mathrm{SO}_{4}$ buffer at $\mathrm{pH}=3.0$ (green) and 2.0 (blue), at $0.1 \mathrm{~V} / \mathrm{s}$. POM concentration: $[\mathbf{3 a}]=0.195 \mathrm{mM}$. 
The cyclic voltammograms exhibit two reversible waves, the first one having an apparent redox potential $\left(\mathrm{E}^{0^{\prime}}\right)$ around $-860 \mathrm{mV}$, and the other one a $\mathrm{E}^{0}$ ' around $-960 \mathrm{mV}$. The electrochemical signals depend on the nature of the working electrode. The best defined signals were obtained on edge-plane pyrolytic graphite (EPG) electrodes (Figure S7). The electrochemical signal of the target compounds is related to the delocalised reduction of their $\mathrm{W}^{6+}$ centres. Indeed, the lanthanides do not have an electrochemical signature in the potential window explored except for europium. ${ }^{[6 a, 38]} A$ controlled-potential coulometry study indicated that there are 16 electrons involved in the total reduction of a molecule of $\mathrm{POM}$ carried out at a potential corresponding to the first wave of the voltammogram. The shape of the anodic peak of the first wave depends on the vertex potential. When both waves are swept, a shoulder is visible after the anodic peak of the first wave. This shoulder is not observed when the scan is reversed right after the cathodic peak of the first wave, suggesting that an adsorption process followed by the decomposition of the compound on the electrode surface could be operative upon reaching the second wave. This hypothesis is corroborated by the observation of a peak potential difference of less than $60 \mathrm{mV}$ in the second wave. The evolution of the cathodic peak current of the first wave as a function of the square root of the scan rate is linear, again being consistent with a diffusion-controlled system (Figure S8). The electrochemical behaviour as a function of the $\mathrm{pH}$ of the target compounds is shown in Figure 5 and summarised in Table S3. As the pH decreases, the cyclic voltammogram waves of $\mathbf{3} \mathbf{a}$ are shifted to positive values, indicating that the electron transfer is accompanied by proton transfer. Unfortunately, it is difficult to evaluate the evolution of the apparent redox potential of each wave as a function of the $\mathrm{pH}$, because the anodic peak is poorly defined for $\mathrm{pH}$ values below 5.0.

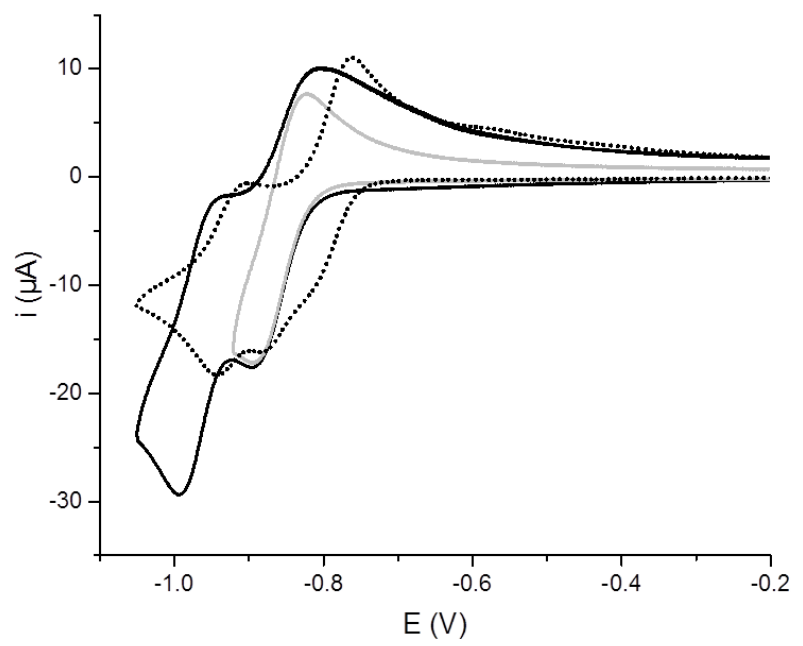

Figure 6. Cyclic voltammograms normalised with respect to the concentration of $\mathbf{1 a}$ (dashed line), $\mathbf{2 a}$ (grey line) and the ligand (black line), recorded in $0.4 \mathrm{M}$ $\mathrm{LiCH}_{3} \mathrm{COO} / \mathrm{CH}_{3} \mathrm{COOH}$ at $\mathrm{pH}=5.0$, at $v=0.1 \mathrm{~V} / \mathrm{s}$

If a rapid electron transfer is assumed at all $\mathrm{pH}$ values, then the peak potential difference $\left(\Delta E=E_{p a 1}-E_{p c 1}\right)$ should be constant. Thus, plotting the evolution of $E_{p c 1}$ as a function of the $\mathrm{pH}$ for the different compounds gives slopes close to $-80 \mathrm{mV} / \mathrm{pH}$ unit. This result does not allow to draw a conclusion on the value of the ratio "number of protons exchanged/number of electrons exchanged" involved in the redox process of the first wave of the cyclic voltammogram for each compound. The cyclic voltammogram of Eu (2a) shows waves of greater intensity than Sm (1a) (and other similar compounds, Figure S6). The first process is composite with a shoulder at $-0.770 \mathrm{~V}$ vs SCE on the cathodic wave and a splitting on the anodic wave (Figure 6). The shoulder at $-0.770 \mathrm{~V}$ vs SCE may be attributed to the electrochemical signal of the $\mathrm{Eu}^{3+}$ ions. ${ }^{[7,39,40]}$

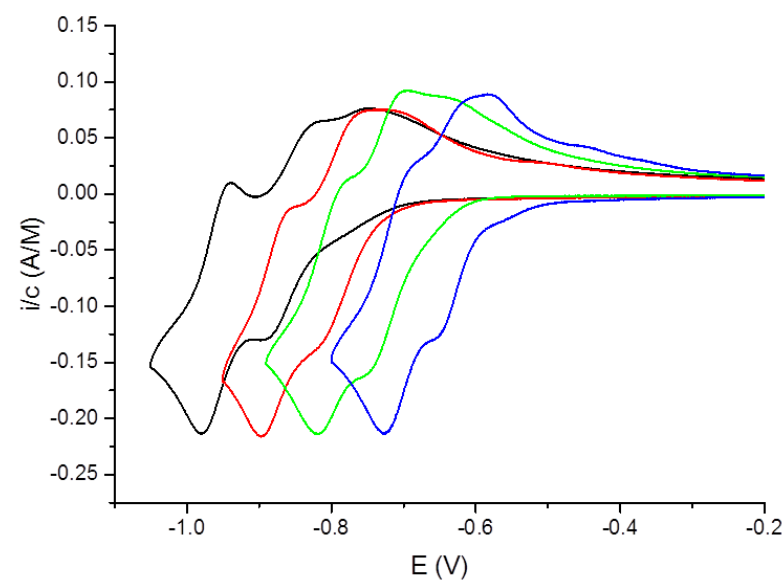

Figure 7. Cyclic voltammograms of Eu (2a) normalised with respect to the concentration as a function of the $\mathrm{pH}$, recorded in $0.4 \mathrm{M}$ $\mathrm{LiCH}_{3} \mathrm{COO} / \mathrm{CH}_{3} \mathrm{COOH}$ at $\mathrm{pH}=5.0$ (black) and 4.0 (red), and in $0.2 \mathrm{M}$ $\mathrm{Na}_{2} \mathrm{SO}_{4} / \mathrm{H}_{2} \mathrm{SO}_{4}$ buffer at $\mathrm{pH}=3.0$ (green) and 2.0 (blue), at $0.1 \mathrm{~V} / \mathrm{s}$.

Indeed, in this potential range, the lacunary species does not exhibit any electrochemical signal, and the shoulder thus observed is similar to the signal observed with $\mathrm{EuCl}_{3}$ (Figure S9). The study of the electrochemical signal as a function of the scan rate shows again that the compound is freely diffusing in solution (Figure S10). As the $\mathrm{pH}$ decreases, the waves in the cyclic voltammogram of $\mathrm{Eu} \mathrm{(2a)}$ are shifted to positive values indicating that the electron transfer is accompanied by proton transfer (Figure 7). Unfortunately, it is difficult to evaluate the evolution of the apparent redox potential of each wave as a function of the $\mathrm{pH}$, because the anodic peak is poorly defined for $\mathrm{pH}$ values below 5.0. The Epc1 values evolve by about $-77 \mathrm{mV}$ per $\mathrm{pH}$ unit. Again, this result does not allow to draw a conclusion on the value of the ratio "number of protons exchanged/number of electrons exchanged" involved in the redox process of the first wave of the cyclic voltammogram.

\section{Conclusion}

In conclusion, we have reported a series of ten lanthanidesubstituted silicotungstates of formula $\mathrm{K}_{11} \mathrm{Na}_{15}\left[\left(\mathrm{Ln}_{2} \mathrm{SiW}_{10} \mathrm{O}_{38}\right)_{4}\left(\mathrm{~W}_{3} \mathrm{O}_{8}\right)(\mathrm{OH})_{4}\left(\mathrm{H}_{2} \mathrm{O}\right)_{2}\right]\left[\mathrm{Ln}^{\mathrm{III}}=\mathrm{Sm}(\mathbf{1 a}), \mathrm{Eu}\right.$ (2a), Gd (3a), Tb (4a), Dy (5a), Ho (6a), Er (7a), Tm (8a), Yb (9a), $Y(\mathbf{1 0 a})$ ]. All the isolated complexes are characterized by various analytical techniques such as FT-IR, UV/Vis spectroscopy, TGA, ICP-AES, SC-XRD, and P-XRD. The single crystal $\mathrm{X}$-ray diffraction reveals that all the complexes are isostructural and crystallize in the monoclinic crystal system with the space group $P-1$. The complexes $\mathbf{1 a}, \mathbf{2 a}$ and $\mathbf{5 a}$ show excellent photoluminescence properties. The complexes were used as catalysts for the oxidation of various thioethers and 
show good catalytic activity. In addition, the electrochemistry properties of the complexes were also investigated.

\section{Experimental Section}

\section{Materials and Methods}

The trilacunary $\mathrm{Na}_{10}\left[\mathrm{~A}-\alpha-\mathrm{SiW}_{9} \mathrm{O}_{34}\right] \cdot 16 \mathrm{H}_{2} \mathrm{O}$ precursor was prepared according to the published literature. ${ }^{[41]}$ The FT-IR spectra of all the complexes were recorded on Perkin-Elmer $\mathrm{BX}$ spectrometer on $\mathrm{KBr}$ pellets in the range of $400-1400 \mathrm{~cm}^{-1}$. Liquid UV/Vis spectroscopy was investigated on Analytic Jena Specord 250 spectrometer. Single crystal X-ray diffraction data were obtained by using an Xcalibur Oxford diffractometer operated at $50 \mathrm{kV}$ and $40 \mathrm{~mA}$ (Mo $\mathrm{K}_{\mathrm{a} 1}$ radiation). Thermogravimetric analysis was performed on a DTG-60 TG/DTA instrument (Shimadzu) in the temperature range $30-400{ }^{\circ} \mathrm{C}$. The catalytic study of the oxidation of thioethers was performed using Gas chromatography (GC Plus 2010 Shimadzu). Solid state UV/Vis spectra were recorded with a Thermo Scientific Evolution 300 spectrometer. Photoluminescence spectra were obtained with the help of a Fluorolog Horiba Jobin Yvon spectrometer. Elemental analysis was performed with an ICP-AES ARCOS instrument from $\mathrm{M} / \mathrm{s}$ Spectro Germany. Electrochemical data was obtained using an Autolab PGSTAT 128N driven by a PC with the NOVA software. A one-compartment cell with a standard three electrode configuration was used for cyclic voltammetry experiments. The reference electrode was a saturated calomel electrode (SCE) and the counter electrode, a platinum plate of large surface area. The reference electrode was separated from the bulk electrolyte solution via a fritted compartment filled with the same electrolyte. The working electrode was a $3 \mathrm{~mm}$ diameter disk made of edge-plane pyrolytic graphite (EPG - Mersen). Before each run, the working electrode was polished with a $1 \mu \mathrm{m}$ grain size diamond paste (DP Diamond-Struers) during $2 \mathrm{~min}$ and washed in an ultrasonic bath of ethanol during $2 \mathrm{~min}$. Prior to each experiment, solutions were thoroughly deaerated with pure argon. A positive pressure of this gas was maintained during subsequent work. All experiments were performed at room temperature, which is controlled and fixed for the lab at $20^{\circ} \mathrm{C}$. Pure water obtained with a Milli$Q$ Integral 5 purification set was used throughout. All reagents were of high-purity grade and were used as purchased from Sigma Aldrich without further purification: $\mathrm{CH}_{3} \mathrm{COOH}$ (glacial acetic acid), $\mathrm{LiCH}_{3} \mathrm{COO}$, $\mathrm{Na}_{2} \mathrm{SO}_{4}$ and $\mathrm{H}_{2} \mathrm{SO}_{4}$. Powder X-ray diffraction was carried out in high resolution Rigaku $\mathrm{X}$-ray diffractometer employing Cu-Ka radiation $(\lambda=$ $1.5406 \AA$ ) at $298 \mathrm{~K}$ in the range of $2 \theta=5^{\circ}-30^{\circ}$.

\section{Synthesis of $\mathrm{K}_{11} \mathrm{Na}_{15}\left[\left(\mathrm{Sm}_{2} \mathrm{SiW}_{10} \mathrm{O}_{38}\right)_{4}\left(\mathrm{~W}_{3} \mathrm{O}_{8}\right)(\mathrm{OH})_{4}\left(\mathrm{H}_{2} \mathrm{O}\right)_{2}\right] \cdot 58 \mathrm{H}_{2} \mathrm{O}(1 \mathrm{a})$}

$0.0889 \mathrm{~g}$ of $\mathrm{Sm}\left(\mathrm{NO}_{3}\right)_{3} \cdot 6 \mathrm{H}_{2} \mathrm{O}(0.2 \mathrm{mmol})$ was dissolved in $25 \mathrm{~mL}$ of 0.25 $\mathrm{M}$ potassium chloride solution. Subsequently, $0.2546 \mathrm{~g}$ of $\mathrm{Na}{ }_{10}[\mathrm{~A}-\alpha$ $\left.\mathrm{SiW}_{9} \mathrm{O}_{34}\right] \cdot 16 \mathrm{H}_{2} \mathrm{O}(0.1 \mathrm{mmol})$ was added to the above solution with continuous stirring and the reaction mixture was heated at $80^{\circ} \mathrm{C}$ for $1 \mathrm{~h}$. Thereafter, the reaction mixture was cooled at room temperature and filtered. The filtrate was left for slow evaporation in order to obtain blockshaped crystals after 2 days. The crystals were collected with a yield of $60 \mathrm{mg}\left(23 \%\right.$ based on $\mathrm{Na}_{10}\left[\mathrm{~A}-\alpha-\mathrm{SiW}_{9} \mathrm{O}_{34}\right] \cdot 16 \mathrm{H}_{2} \mathrm{O}$ ). FT-IR: $\bar{v}=997$ (s), 936 (s), 897 (s), 853 (s) $\mathrm{cm}^{-1}$. Elemental analysis (\%) calcd (found): Na 2.52 (2.83), K 3.14 (4.01), W 57.68 (58.10), Si $0.82(0.86)$. The number of water molecules was calculated by TGA.

\section{Synthesis of $\mathrm{K}_{18} \mathrm{Na}_{8}\left[\left(\mathrm{Eu}_{2} \mathrm{SiW}_{10} \mathrm{O}_{38}\right)_{4}\left(\mathrm{~W}_{3} \mathrm{O}_{8}\right)(\mathrm{OH})_{4}\left(\mathrm{H}_{2} \mathrm{O}\right)_{2}\right] \cdot 62 \mathrm{H}_{2} \mathrm{O}(2 \mathrm{a})$}

The above synthetic protocol procedure was followed by using $\mathrm{Eu}\left(\mathrm{NO}_{3}\right)_{3} \cdot 5 \mathrm{H}_{2} \mathrm{O}(0.0856 \mathrm{~g}, 0.2 \mathrm{mmol})$ instead of $\mathrm{Sm}\left(\mathrm{NO}_{3}\right)_{3} \cdot 6 \mathrm{H}_{2} \mathrm{O}$. Crystals were collected with a yield of $55 \mathrm{mg}\left(21 \%\right.$ based on $\mathrm{Na}_{10}[\mathrm{~A}-\alpha-$ $\left.\mathrm{SiW}_{9} \mathrm{O}_{34}\right] \cdot 16 \mathrm{H}_{2} \mathrm{O}$ ). FT-IR: $\bar{v}=997$ (s), $950(\mathrm{~s}), 882$ (s), 851 (s), $750 \mathrm{~cm}^{-1}$. Elemental analysis (\%) calcd (found): $\mathrm{Na} 1.32(1.58), \mathrm{K} 5.06$ (6.00), W
$56.86(57.60)$, Si $0.81(0.90)$. The number of water molecules was calculated by TGA.

\section{Synthesis of $\mathrm{K}_{16} \mathrm{Na}_{10}\left[\left(\mathrm{Gd}_{2} \mathrm{SiW}_{10} \mathrm{O}_{38}\right)_{4}\left(\mathrm{~W}_{3} \mathrm{O}_{8}\right)(\mathrm{OH})_{4}\left(\mathrm{H}_{2} \mathrm{O}\right)_{2}\right] \cdot 59 \mathrm{H}_{2} \mathrm{O}$ (3a)}

The above synthetic protocol procedure was followed by using $\mathrm{Gd}\left(\mathrm{NO}_{3}\right)_{3} \cdot 6 \mathrm{H}_{2} \mathrm{O}(0.0903 \mathrm{~g}, 0.2 \mathrm{mmol})$ instead of $\mathrm{Sm}\left(\mathrm{NO}_{3}\right)_{3} \cdot 6 \mathrm{H}_{2} \mathrm{O}$ Crystals were collected with a yield of $57 \mathrm{mg}\left(22 \%\right.$ based on $\mathrm{Na}_{10}[\mathrm{~A}-\alpha-$ $\left.\left.\mathrm{SiW}_{9} \mathrm{O}_{34}\right] \cdot 16 \mathrm{H}_{2} \mathrm{O}\right)$. FT-IR: $\bar{v}=999$ (s), $946(\mathrm{~s}), 885(\mathrm{~s}), 856(\mathrm{~s}), 745 \mathrm{~cm}^{-1}$ Elemental analysis (\%) calcd (found): Na 1.66 (1.80), K 4.50 (4.90), W 56.91 (58.03), Si 0.81 (0.92). The number of water molecules was calculated by TGA.

\section{Synthesis of $\mathrm{K}_{15} \mathrm{Na}_{11}\left[\left(\mathrm{~Tb}_{2} \mathrm{SiW}_{10} \mathrm{O}_{38}\right)_{4}\left(\mathrm{~W}_{3} \mathrm{O}_{8}\right)(\mathrm{OH})_{4}\left(\mathrm{H}_{2} \mathrm{O}\right)_{2}\right] \cdot 60 \mathrm{H}_{2} \mathrm{O}(4 \mathrm{a})$}

The above synthetic protocol procedure was followed by using $\mathrm{Tb}\left(\mathrm{NO}_{3}\right)_{3} \cdot 5 \mathrm{H}_{2} \mathrm{O}(0.087 \mathrm{~g}, 0.2 \mathrm{mmol})$ instead of $\mathrm{Sm}\left(\mathrm{NO}_{3}\right)_{3} \cdot 6 \mathrm{H}_{2} \mathrm{O}$. Crystals were collected with a yield of $72 \mathrm{mg}\left(28 \%\right.$ based on $\mathrm{Na}_{10}[\mathrm{~A}-\alpha-$ $\left.\mathrm{SiW}_{9} \mathrm{O}_{34}\right] \cdot 16 \mathrm{H}_{2} \mathrm{O}$ ). FT-IR: $\bar{v}=1002$ (s), $941(\mathrm{~s}), 896(\mathrm{~s}), 855(\mathrm{~s}), 760 \mathrm{~cm}^{-1}$ Elemental analysis (\%) calcd (found): Na 1.82 (1.92), K 4.22 (4.75), W 56.85 (57.20), Si $0.81(0.87)$. The number of water molecules was calculated by TGA.

\section{Synthesis of $\mathrm{K}_{19} \mathrm{Na}_{7}\left[\left(\mathrm{Dy}_{2} \mathrm{SiW}_{10} \mathrm{O}_{38}\right)_{4}\left(\mathrm{~W}_{3} \mathrm{O}_{8}\right)(\mathrm{OH})_{4}\left(\mathrm{H}_{2} \mathrm{O}\right)_{2}\right] \cdot 68 \mathrm{H}_{2} \mathrm{O}(5 \mathrm{a})$}

The above synthetic protocol procedure was followed by using $\operatorname{Dy}\left(\mathrm{NO}_{3}\right)_{3} \cdot \mathrm{H}_{2} \mathrm{O}(0.0877 \mathrm{~g}, 0.2 \mathrm{mmol})$ instead of $\mathrm{Sm}\left(\mathrm{NO}_{3}\right)_{3} \cdot 6 \mathrm{H}_{2} \mathrm{O}$. Crystals were collected with a yield of $77 \mathrm{mg}\left(30 \%\right.$ based on $\mathrm{Na}_{10}[\mathrm{~A}-\alpha-$ $\left.\mathrm{SiW}_{9} \mathrm{O}_{34}\right] \cdot 16 \mathrm{H}_{2} \mathrm{O}$ ). FT-IR: $\bar{v}=1000$ (s), 940 (s), 890 (s), 857 (s), 761 (m), $715(\mathrm{w}) \mathrm{cm}^{-1}$. Elemental analysis (\%) calcd (found): $\mathrm{Na} 1.14$ (1.81), $\mathrm{K}$ 5.25 (5.60), W 55.90 (57.10), Si $0.79(0.87)$. The number of water molecules was calculated by TGA.

\section{Synthesis of $\mathrm{K}_{20} \mathrm{Na}_{6}\left[\left(\mathrm{Ho}_{2} \mathrm{SiW}_{10} \mathrm{O}_{38}\right)_{4}\left(\mathrm{~W}_{3} \mathrm{O}_{8}\right)(\mathrm{OH})_{4}\left(\mathrm{H}_{2} \mathrm{O}\right)_{2}\right] \cdot 57 \mathrm{H}_{2} \mathrm{O}(6 \mathrm{a})$}

The above synthetic protocol procedure was followed by using $\mathrm{Ho}\left(\mathrm{NO}_{3}\right)_{3} \cdot 5 \mathrm{H}_{2} \mathrm{O}(0.0882 \mathrm{~g}, 0.2 \mathrm{mmol})$ instead of $\mathrm{Sm}\left(\mathrm{NO}_{3}\right)_{3} \cdot 6 \mathrm{H}_{2} \mathrm{O}$. Crystals were collected with a yield of $57 \mathrm{mg}\left(22 \%\right.$ based on $\mathrm{Na}_{10}[\mathrm{~A}-\alpha-$ $\left.\mathrm{SiW}_{9} \mathrm{O}_{34}\right] \cdot 16 \mathrm{H}_{2} \mathrm{O}$ ). FT-IR: $\bar{v}=1005$ (s), 950 (s), 880 (s), 857 (s), 755 (m) $\mathrm{cm}^{-1}$. Elemental analysis (\%) calcd (found): Na 0.99 (1.11), K 5.59 (6.02) W 56.55 (57.02) Si $0.80(0.87)$. The number of water molecules was calculated by TGA.

\section{Synthesis of $\mathrm{K}_{16} \mathrm{Na}_{10}\left[\left(\mathrm{Er}_{2} \mathrm{SiW}_{10} \mathrm{O}_{38}\right)_{4}\left(\mathrm{~W}_{3} \mathrm{O}_{8}\right)(\mathrm{OH})_{4}\left(\mathrm{H}_{2} \mathrm{O}\right)_{2}\right] \cdot 60 \mathrm{H}_{2} \mathrm{O}(7 \mathrm{a})$}

The above synthetic protocol procedure was followed by using $\mathrm{Er}\left(\mathrm{NO}_{3}\right)_{3} \cdot 5 \mathrm{H}_{2} \mathrm{O}(0.0886 \mathrm{~g}, 0.2 \mathrm{mmol})$ instead of $\mathrm{Sm}\left(\mathrm{NO}_{3}\right)_{3} \cdot 6 \mathrm{H}_{2} \mathrm{O}$. Crystals were collected with a yield of $62 \mathrm{mg}\left(24 \%\right.$ based on $\mathrm{Na}_{10}[\mathrm{~A}-\alpha$ $\left.\mathrm{SiW}_{9} \mathrm{O}_{34}\right] \cdot 16 \mathrm{H}_{2} \mathrm{O}$ ). FT-IR: $\bar{v}=1002$ (s), 943 (s), 888 (s), 859 (s), 750 (w) $\mathrm{cm}^{-1}$. Elemental analysis (\%) calcd (found): Na 1.64 (1.89), K 4.47 (5.02), W 56.51 (58.10), Si $0.80(0.86)$. The number of water molecules was calculated by TGA.

\section{Synthesis of $\mathrm{K}_{11} \mathrm{Na}_{15}\left[\left(\mathrm{Tm}_{2} \mathrm{SiW}_{10} \mathrm{O}_{38}\right)_{4}\left(\mathrm{~W}_{3} \mathrm{O}_{8}\right)(\mathrm{OH})_{4}\left(\mathrm{H}_{2} \mathrm{O}\right)_{2}\right] \cdot 57 \mathrm{H}_{2} \mathrm{O}(8 \mathrm{a})$}

The above synthetic protocol procedure was followed by using $\mathrm{Tm}\left(\mathrm{NO}_{3}\right)_{3} \cdot 5 \mathrm{H}_{2} \mathrm{O}(0.089 \mathrm{~g}, 0.2 \mathrm{mmol})$ instead of $\mathrm{Sm}\left(\mathrm{NO}_{3}\right)_{3} \cdot 6 \mathrm{H}_{2} \mathrm{O}$. Crystals were collected with a yield of $54 \mathrm{mg}\left(21 \%\right.$ based on $\mathrm{Na}{ }_{10}[\mathrm{~A}-\alpha-$ $\left.\mathrm{SiW}_{9} \mathrm{O}_{34}\right] \cdot 16 \mathrm{H}_{2} \mathrm{O}$ ). FT-IR: $\bar{v}=1006$ (s), 943(s), $892(\mathrm{~s}), 857$ (s), 760 (w) $\mathrm{cm}^{-1}$. Elemental analysis (\%) calcd (found): Na 2.49 (2.86), K 3.10 (3.48) W 56.97 (57.15), Si $0.81(0.89)$. The number of water molecules was calculated by TGA.

Synthesis of $\mathrm{K}_{11} \mathrm{Na}_{15}\left[\left(\mathrm{Yb}_{2} \mathrm{SiW}_{10} \mathrm{O}_{38}\right)_{4}\left(\mathrm{~W}_{3} \mathrm{O}_{8}\right)(\mathrm{OH})_{4}\left(\mathrm{H}_{2} \mathrm{O}\right)_{2}\right] \cdot 56 \mathrm{H}_{2} \mathrm{O}(9 \mathrm{a})$ 
The above synthetic protocol procedure was followed by using $\mathrm{Yb}\left(\mathrm{NO}_{3}\right)_{3} \cdot 5 \mathrm{H}_{2} \mathrm{O}(0.0898 \mathrm{~g}, 0.2 \mathrm{mmol})$ instead of $\mathrm{Sm}\left(\mathrm{NO}_{3}\right)_{3} \cdot 6 \mathrm{H}_{2} \mathrm{O}$. Crystals were collected with a yield of $59 \mathrm{mg}$ (23\% based on $\mathrm{Na}_{10}[\mathrm{~A}-\alpha$ $\left.\left.\mathrm{SiW}_{9} \mathrm{O}_{34}\right] \cdot 16 \mathrm{H}_{2} \mathrm{O}\right)$. FT-IR: $\bar{v}=1008$ (s), 946 (s), $896(\mathrm{~s}), 853(\mathrm{~s}), 765(\mathrm{w})$ $\mathrm{cm}^{-1}$. Elemental analysis (\%) calcd (found): Na 2.49 (2.60), K 3.11 (4.01), W 57.08 (58.12), Si 0.81 (0.83). The number of water molecules was calculated by TGA.

\section{Synthesis of $\mathrm{K}_{11} \mathrm{Na}_{15}\left[\left(\mathrm{Y}_{2} \mathrm{SiW}_{10} \mathrm{O}_{38}\right)_{4}\left(\mathrm{~W}_{3} \mathrm{O}_{8}\right)(\mathrm{OH})_{4}\left(\mathrm{H}_{2} \mathrm{O}\right)_{2}\right] \cdot 55 \mathrm{H}_{2} \mathrm{O}(10 \mathrm{a})$}

The above synthetic protocol procedure was followed by using $\mathrm{Y}\left(\mathrm{NO}_{3}\right)_{3} \cdot 6 \mathrm{H}_{2} \mathrm{O}(0.0766 \mathrm{~g}, 0.2 \mathrm{mmol})$ instead of $\mathrm{Sm}\left(\mathrm{NO}_{3}\right)_{3} \cdot 6 \mathrm{H}_{2} \mathrm{O}$. Crystals were collected with a yield of $67 \mathrm{mg}\left(26 \%\right.$ based on $\mathrm{Na}_{10}[\mathrm{~A}-\alpha$ $\left.\mathrm{SiW}_{9} \mathrm{O}_{34}\right] \cdot 16 \mathrm{H}_{2} \mathrm{O}$ ). FT-IR: $\bar{v}=1003$ (s), 940 (s), 895 (s), 855 (s), 760 (w) $\mathrm{cm}^{-1}$. Elemental analysis (\%) calcd (found). Na 1.61 (1.67), K 3.36 (3.69), W 59.89 (60.95), Si $0.85(0.90)$. The number of water molecules was calculated by TGA.

\section{X-ray crystallography}

Single crystals of 1a-10a suitable for X-ray diffraction were mounted on a capillary tube for indexing and intensity data collection at $192 \mathrm{~K}$. An Xcalibur Oxford diffractometer was used which operated at $50 \mathrm{kV}$ and 40 $\mathrm{mA}$ (Mo $\mathrm{K}_{\alpha}, \lambda=0.71073 \AA$, graphite monochromated). ${ }^{[42]}$ Pre-experiment, data collection and data reduction were performed with the Oxford program suite CrysAlisPro. ${ }^{[43]}$ An empirical adsorption correction based on symmetry equivalent reflections was applied using SCALE3 ABSPACK. ${ }^{[44]}$ The crystal structure was solved by direct methods using SHELXS-2008, ${ }^{[45]}$ which located all the heavy metal atoms (W and Ln) and enabled us to locate all the positions of other non-hydrogen atoms $(\mathrm{O}, \mathrm{K}, \mathrm{Na}, \mathrm{Si})$ from the difference Fourier maps. The last cycles of refinement included atomic positions, anisotropic thermal parameters for all the heavy metal atoms and isotropic thermal parameters for all other non-hydrogen $(\mathrm{O})$ atoms. Some of the tungsten atoms were refined with partial occupancies and isotropic due to disorder. Due to disorder, the Rfactor for some of the crystals are higher than usual but, the strcuture has been solved with utmost precision as possible. Some of the oxygen atoms are disorderd water molecules and as a result the structure has solvent accessible voids. The data obtained are Full-matrix least squares structure refinement against $\left|\mathrm{F}^{2}\right|$ was performed using the SHELXL-2015 package of programs. ${ }^{[45]}$ The crystal data is shown in Table 4. Further, details of the crystal structure data may be obtained from Fachinformationszentrum Karlsruhe, 76344 [Eggenstein-leopoldshafen, Germeny Fax: (+49) 7247-808-666; e-mail: crysdata@fiz-karlsruhe.de] on quoting the depository number CSD 1979347 for $\mathbf{2 a}, 2045339$ for $\mathbf{3 a}$, 1979348 for $\mathbf{4 a}, 2045340$ for $\mathbf{5 a}, 2045341$ for $\mathbf{6 a}, 1979349$ for $\mathbf{7 a}$, 2045342 for $\mathbf{8 a}, 2045343$ for $9 \mathbf{a}$ and 1979350 for $\mathbf{1 0 a}$

\section{FTIR Spectroscopy}

FT-IR spectra of all the complexes 1a-10a were recorded on a PerkinElmer $\mathrm{BX}$ spectrometer using $\mathrm{KBr}$ pellets. All complexes show similar spectral patterns. The finger-print region of $P O M$ ligands is in the range from $1000-400 \mathrm{~cm}^{-1}$ and in this region four major characteristic vibration bands (asymmetric) are obtained, which are attributed to $\mathrm{v}_{\mathrm{as}}(\mathrm{Si}-$ $\left.\mathrm{O}_{\mathrm{a}}\right)$, terminal $\mathrm{v}_{\mathrm{as}}\left(\mathrm{W}-\mathrm{O}_{\mathrm{t}}\right)$, corner sharing $\mathrm{v}_{\mathrm{as}}\left(\mathrm{W}-\mathrm{O}_{\mathrm{b}}-\mathrm{W}\right)$, and edge-sharing $\mathrm{V}_{\mathrm{as}}\left(\mathrm{W}-\mathrm{O}_{\mathrm{c}}-\mathrm{W}\right)$. The asymmetric vibration bands at $1000-1005 \mathrm{~cm}^{-1}$ are ascribed to $\mathrm{V}_{\mathrm{as}}\left(\mathrm{Si}-\mathrm{O}_{\mathrm{a}}\right)$ and the bands at around $935-940 \mathrm{~cm}^{-1}$ are assigned to $\mathrm{Vas}_{\mathrm{as}}\left(\mathrm{W}=\mathrm{O}_{\mathrm{t}}\right)$, these bands being considered as pure vibrational bands of the POM ligands. The vibration frequency in the range of 885 $890 \mathrm{~cm}^{-1}$ is attributed to $\mathrm{V}_{\mathrm{as}}\left(\mathrm{W}-\mathrm{O}_{\mathrm{b}}-\mathrm{W}\right)$, and the peaks at $850-855$ and

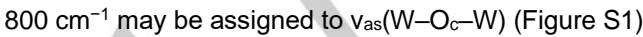

\section{UV/Vis Spectroscopy}

The liquid UV/Vis spectra of all the complexes 1a-10a show two characteristic absorption bands: a strong band at around $240 \mathrm{~nm}$ and another broad band at around 190-200 $\mathrm{nm}$. The higher energy absorption band may be attributed to $p \pi-d \pi$ charge transfer transitions of terminal $O$ $\rightarrow \mathrm{W}$ bonds, and the lower energy band is due to $p \pi-d \pi$ charge transfer transitions of $\mathrm{O}_{\mathrm{b}, \mathrm{c}} \rightarrow \mathrm{W}$ bonds (Figure S2). We have also recorded the solid UV/Vis spectra of which the absorbance peaks are seen in three complexes (Figure S3). The complex Sm (1a) shows nine characteristic absorbance peaks in which two are in the UV region and the others belong to the visible range. Two absorbance peaks in the UV region are ascribed to ${ }^{6} \mathrm{H}_{5 / 2} \rightarrow{ }^{2} \mathrm{D}_{1 / 2}$ and ${ }^{6} \mathrm{H}_{5 / 2} \rightarrow{ }^{4} \mathrm{G}_{11 / 2},{ }^{4} \mathrm{H}_{11 / 2}$ transitions at 370 and 390 $\mathrm{nm}$ respectively. Other seven absorbance peaks are assigned as ${ }^{6} \mathrm{H}_{5 / 2} \rightarrow$ ${ }^{4} \mathrm{~K}_{11 / 2},{ }^{6} \mathrm{H}_{5 / 2} \rightarrow{ }^{5} \mathrm{P}_{3 / 2},{ }^{6} \mathrm{P}_{3 / 2},{ }^{6} \mathrm{H}_{5 / 2} \rightarrow{ }^{4} \mathrm{G}_{9 / 2},{ }^{4} \mathrm{I}_{15 / 2},{ }^{6} \mathrm{H}_{5 / 2} \rightarrow{ }^{4} \mathrm{~F}_{5 / 2},{ }^{4} \mathrm{M}_{17 / 2},{ }^{6} \mathrm{H}_{5 / 2} \rightarrow{ }^{4} \mathrm{I}_{11 / 2}$, ${ }^{4} \mathrm{I}_{13 / 2},{ }^{6} \mathrm{H}_{5 / 2} \rightarrow{ }^{4} \mathrm{G}_{7 / 2}$ and ${ }^{6} \mathrm{H}_{5 / 2} \rightarrow{ }^{4} \mathrm{~F}_{3 / 2}$ transitions at $405,425,445,465,485$ 510 and $530 \mathrm{~nm}$ respectively. ${ }^{[46,47]}$ Five excitation peaks for the Eu (2a) complex are observed in the UV/Vis range which are at 362, 382, 395, 416 and $465 \mathrm{~nm}$ corresponding to the ${ }^{7} \mathrm{~F}_{0} \rightarrow{ }^{5} \mathrm{D}_{4},{ }^{7} \mathrm{~F}_{0} \rightarrow{ }^{5} \mathrm{~L}_{7},{ }^{7} \mathrm{~F}_{0} \rightarrow{ }^{5} \mathrm{~L}_{6},{ }^{7} \mathrm{~F}_{0} \rightarrow$ ${ }^{5} D_{3}$ and ${ }^{7} F_{0} \rightarrow{ }^{5} D_{2}$ transitions respectively. The absorbance spectrum of the complex Dy (5a) shows a total of five absorbance peaks, three of them being very weak at 429,454 and $479 \mathrm{~nm}$. They involve excitations from the ${ }^{6} \mathrm{H}_{15 / 2}$ ground state to various excited states, two transitions being highly intense at 758 and $808 \mathrm{~nm}$.

\section{Photoluminescence spectroscopy}

Since polyoxometalates are metal oxide nanoclusters, they have ligand to metal charge transfer properties. Initially, Yamase and co-workers investigated the photoluminescence $(\mathrm{PL})$ properties of all lanthanidesubstituted polyoxometalates. ${ }^{[48,49]}$ All the title polyanions were studied and some of them exhibit good photoluminescence properties on photoexcitation at room temperature. The complex ion 1a shows four emission peaks at 565, 601, 648 and $708 \mathrm{~nm}$ on photo-excitation at $377 \mathrm{~nm}$ (Figure 8). These peaks can be assigned to the corresponding transitions ${ }^{4} \mathrm{G}_{5 / 2} \rightarrow{ }^{6} \mathrm{H}_{5 / 2},{ }^{4} \mathrm{G}_{7 / 2} \rightarrow{ }^{6} \mathrm{H}_{9 / 2}$ and ${ }^{4} \mathrm{G}_{5 / 2} \rightarrow{ }^{6} \mathrm{H}_{11 / 2}$ respectively. All peaks are observed in the visible region. A peak at $565 \mathrm{~nm}$ is known as zero-zero band and another two transitions at 648 and $708 \mathrm{~nm}$ are attributed to ${ }^{4} \mathrm{G}_{5 / 2} \rightarrow{ }^{6} \mathrm{H}_{5 / 2}$ and ${ }^{4} \mathrm{G}_{7 / 2} \rightarrow{ }^{6} \mathrm{H}_{9 / 2}$, known as magnetic dipole and electric dipole transitions, respectively. ${ }^{[46-50]}$ The photoluminescence spectra of the complex $2 \mathbf{a}$ shows five emission peaks at 584, 594, 625, 656 and $704 \mathrm{~nm}$. All five peaks are assigned as ${ }^{5} \mathrm{D}_{0} \rightarrow{ }^{7} \mathrm{~F}_{0},{ }^{5} \mathrm{D}_{0} \rightarrow{ }^{7} \mathrm{~F}_{1},{ }^{5} \mathrm{D}_{0} \rightarrow{ }^{7} \mathrm{~F}_{2},{ }^{5} \mathrm{D}_{0}$ $\rightarrow{ }^{7} \mathrm{~F}_{3},{ }^{5} \mathrm{D}_{0} \rightarrow{ }^{7} \mathrm{~F}_{3}$, and ${ }^{5} \mathrm{D}_{0} \rightarrow{ }^{7} \mathrm{~F}_{4}$ respectively (Figure 9).

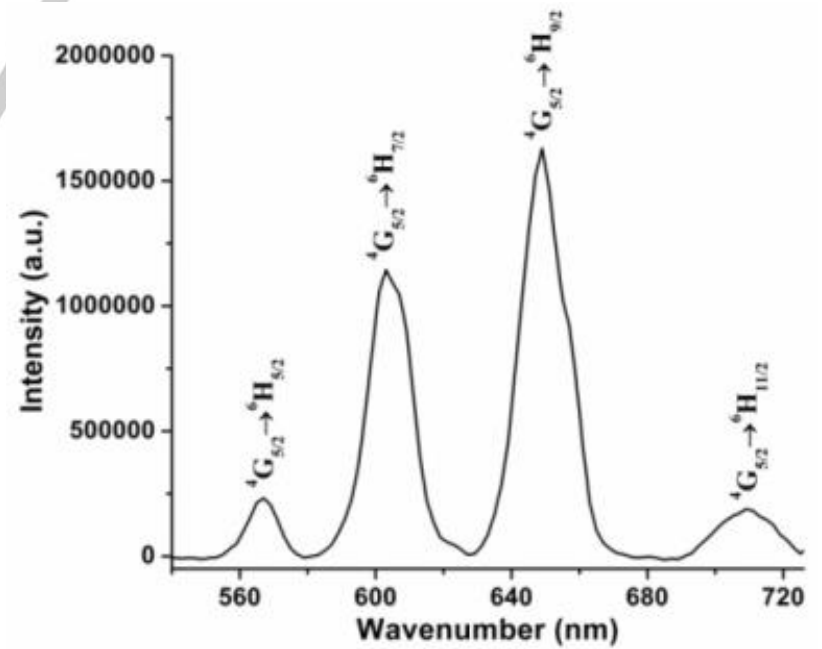

Figure 8. The photoluminescence spectrum of the complex Sm (1a) excitation at $377 \mathrm{~nm}$.

The transition assigned as ${ }^{5} D_{0} \rightarrow{ }^{7} F_{1}$ is magnetic dipole in nature and the intensity is independent from the environment of the $\mathrm{Eu}^{3+}$ ion, but directly affected by the crystal-field strength of the attached ligands. Transitions ${ }^{5} D_{0} \rightarrow{ }^{7} F_{2}$ and ${ }^{5} D_{0} \rightarrow{ }^{7} F_{4}$ are electric dipole ones, which are influenced by the chemical environment of the $\mathrm{Eu}^{3+}$ ion. The transition assigned as ${ }^{5} \mathrm{D}_{0}$ $\rightarrow{ }^{7} \mathrm{~F}_{3}$ is very weak, because it is forbidden according to the Judd-Ofelt theory. ${ }^{[51,52]}$ The PL spectra of the complex 5 a shows three characteristic emission peaks at 485,574 and 664 which are assigned as ${ }^{4} \mathrm{~F}_{9 / 2} \rightarrow{ }^{6} \mathrm{H}_{15 / 2}$, 
Table 4. Crystal data and refinement

\begin{tabular}{|c|c|c|c|c|c|}
\hline & $\mathrm{Eu}(2 \mathrm{a})$ & Gd(3a) & $\mathrm{Tb}(4 a)$ & $\operatorname{Dy}(5 a)$ & Ho(5a) \\
\hline Empirical formula & $\mathrm{K}_{18} \mathrm{Na}_{8} \mathrm{Eu}_{8} \mathrm{Si}_{4} \mathrm{~W}_{43} \mathrm{O}_{228} \mathrm{H}_{132}$ & $\mathrm{~K}_{16} \mathrm{Na}_{10} \mathrm{Gd}_{8} \mathrm{Si}_{4} \mathrm{~W}_{43} \mathrm{O}_{227} \mathrm{H}_{126}$ & $\mathrm{~K}_{15} \mathrm{Na}_{11} \mathrm{~Tb}_{8} \mathrm{Si}_{4} \mathrm{~W}_{43} \mathrm{O}_{228} \mathrm{H}_{128}$ & $\mathrm{~K}_{19} \mathrm{Na}_{7} \mathrm{Dy}_{8} \mathrm{Si}_{4} \mathrm{~W}_{43} \mathrm{O}_{236} \mathrm{H}_{144}$ & $\mathrm{~K}_{20} \mathrm{Na}_{6} \mathrm{Ho}_{8} \mathrm{Si}_{4} \mathrm{~W}_{43} \mathrm{O}_{225} \mathrm{H}_{122}$ \\
\hline Formula weight & 13901.77 & 13889.79 & 13905.10 & 14142.25 & 13979.64 \\
\hline Crystal system & Triclinic & Triclinic & Triclinic & Triclinic & Triclinic \\
\hline Space group & $P-1$ & $P-1$ & $P-1$ & $P-1$ & $P-1$ \\
\hline $\mathbf{a} / \mathbf{A}$ & $19.6970(4)$ & $19.6503(6)$ & $19.6505(4)$ & $19.7120(3)$ & $19.6104(2)$ \\
\hline $\mathbf{b} / \AA ̊ \AA$ & $22.5010(5)$ & $22.5510(7)$ & $22.4392(4)$ & 22.3933(4) & $22.3285(2)$ \\
\hline $\mathbf{c} / \AA$ & $27.7261(5)$ & $27.7175(7)$ & $27.5480(5)$ & $27.7268(5)$ & $27.5388(2)$ \\
\hline$\alpha /^{\circ}$ & $85.016(2)$ & $85.001(2)$ & $84.717(2)$ & $84.5880(1)$ & $84.5980(10)$ \\
\hline$\beta /^{\circ}$ & $84.577(2)$ & $84.641(2)$ & $84.288(2)$ & $84.5880(10)$ & $84.2650(10)$ \\
\hline $\mathrm{Y} /{ }^{\circ}$ & $68.450(2)$ & $68.218(3)$ & $68.323(2)$ & $68.833(2)$ & $68.5000(10)$ \\
\hline $\mathrm{V} / \AA^{3}$ & $11360.1(4)$ & $11337.5(6)$ & $11211.9(4)$ & $11341.3(4)$ & $11141.66(2)$ \\
\hline $\mathbf{Z}$ & 1 & 1 & 2 & 2 & 1 \\
\hline$D_{c} / g_{~ c m}{ }^{-3}$ & 3.798 & 3.898 & 3.952 & 3.888 & 3.870 \\
\hline$\mu / \mathrm{mm}^{-1}$ & 24.181 & 25.41 & 24.824 & 25.832 & 25.241 \\
\hline$F_{000}$ & 11224 & 11196 & 11546 & 10994 & 11390 \\
\hline Crystal size $/ \mathrm{mm}^{3}$ & $0.08 \times 0.04 \times 0.02$ & $0.08 \times 0.05 \times 0.02$ & $0.07 \times 0.03 \times 0.02$ & $0.10 \times 0.08 \times 0.03$ & $0.10 \times 0.08 \times 0.03$ \\
\hline Reflns collected & 147746 & 153475 & 155783 & 141951 & 177151 \\
\hline Indep refins & 43012 & 42889 & 42498 & 42761 & 45487 \\
\hline $\mathbf{R}_{\text {int }}$ & 0.1107 & 0.1631 & 0.0980 & 0.1649 & 0.0625 \\
\hline $\begin{array}{c}\text { Goodness-of-fit on } \\
F^{2}\end{array}$ & 1.038 & 1.154 & 1.060 & 1.038 & 1.045 \\
\hline$R_{1}[I>2 \sigma(I)]^{a}$ & 0.0808 & 0.1255 & 0.0693 & 0.1323 & 0.0505 \\
\hline \multirow[t]{2}{*}{$w R_{2}$ (all data) ${ }^{b}$} & 0.2288 & 0.3574 & 0.1687 & 0.3176 & 0.1316 \\
\hline & $\operatorname{Er}(6 a)$ & $\operatorname{Tm}(7 a)$ & $\mathrm{Yb}(10 \mathrm{a})$ & $Y(10 a)$ & \\
\hline Empirical formula & $\mathrm{K}_{16} \mathrm{Na}_{10} \mathrm{Er}_{8} \mathrm{Si}_{4} \mathrm{~W}_{43} \mathrm{O}_{228} \mathrm{H}_{128}$ & $\mathrm{~K}_{11} \mathrm{Na}_{15} \mathrm{Tm}_{8} \mathrm{Si}_{4} \mathrm{~W}_{43} \mathrm{O}_{225} \mathrm{H}_{130}$ & $\mathrm{~K}_{11} \mathrm{Na}_{15} \mathrm{Yb}_{8} \mathrm{Si}_{4} \mathrm{~W}_{43} \mathrm{O}_{222} \mathrm{H}_{120}$ & $\mathrm{~K}_{11} \mathrm{Na}_{15} \mathrm{Y}_{8} \mathrm{Si}_{4} \mathrm{~W}_{43} \mathrm{O}_{223} \mathrm{H}_{126}$ & \\
\hline Formula weight & 13987.88 & 13874.75 & 13849.52 & 13198.50 & \\
\hline Crystal system & Triclinic & Triclinic & Triclinic & Triclinic & \\
\hline Space group & $P-1$ & $P-1$ & $P-1$ & $P-1$ & \\
\hline $\mathbf{a} / \mathbf{A}$ & $19.6576(3)$ & $19.6577(6)$ & $19.6283(3)$ & $19.6091(4)$ & \\
\hline $\mathbf{b} / \AA$ & $22.3426(3)$ & $22.2947(6)$ & $22.2290(3)$ & $22.3151(5)$ & \\
\hline $\mathbf{c} / \mathbf{A}$ & $27.6670(5)$ & $27.6328(7)$ & $27.6410(4)$ & $27.5576(6)$ & \\
\hline$\alpha /^{\circ}$ & $84.7030(10)$ & $84.669(2)$ & $84.6040(10)$ & $84.933(2)$ & \\
\hline$\beta /^{\circ}$ & $68.9950(10)$ & $84.780(2)$ & $84.6120(10)$ & $84.527(2)$ & \\
\hline $\mathrm{Y} /^{\circ}$ & $110.653(1)$ & $69.086(3)$ & $69.2110(10)$ & $68.512(2)$ & \\
\hline $\mathrm{V} / \AA^{3}$ & $10998(3)$ & $11241.8(6)$ & $11201.3(3)$ & $11150.8(4)$ & \\
\hline $\mathbf{z}$ & 2 & 2 & 1 & 1 & \\
\hline $\mathrm{D}_{\mathrm{c}} / \mathrm{g} \mathrm{cm}^{-3}$ & 3.908 & 3.859 & 3.952 & 3.733 & \\
\hline$\mu / \mathrm{mm}^{-1}$ & 25.134 & 25.318 & 24.824 & 24.465 & \\
\hline$F_{000}$ & 11454 & 11256 & 11264 & 10884 & \\
\hline Crystal size $/ \mathrm{mm}^{3}$ & $0.07 \times 0.03 \times 0.02$ & $0.09 \times 0.07 \times 0.02$ & $0.06 \times 0.05 \times 0.02$ & $0.08 \times 0.06 \times 0.02$ & \\
\hline Reflns collected & 151119 & 137356 & 177317 & 155995 & \\
\hline Indep refins & 42714 & 38224 & 45587 & 45566 & \\
\hline $\mathbf{R}_{\text {int }}$ & 0.1026 & 0.1633 & 0.1306 & 0.1098 & \\
\hline $\begin{array}{c}\text { Goodness-of-fit on } \\
F^{2}\end{array}$ & 1.053 & 1.044 & 1.075 & 1.028 & \\
\hline$R_{1}[I>2 \sigma(I)]^{a}$ & 0.0708 & 0.1205 & 0.2211 & 0.0698 & \\
\hline$w R_{2}$ (all data) $^{b}$ & 0.2089 & 0.2886 & 0.2369 & 0.1840 & \\
\hline
\end{tabular}

${ }^{\text {[a] }} \mathrm{R}_{1}=\Sigma|| \mathrm{F}_{\mathrm{o}}|-| \mathrm{F}_{\mathrm{c}}|| / \Sigma\left|\mathrm{Fo}_{\mathrm{o}}\right|{ }^{[\mathrm{b}]} \mathrm{wR}_{2}=\left\{\Sigma\left[\mathrm{w}\left(\mathrm{F}_{\mathrm{o}}^{2}-\mathrm{F}_{\mathrm{c}}^{2}\right)^{2}\right] / \Sigma\left[\mathrm{w}\left(\mathrm{F}_{\mathrm{o}}^{2}\right)^{2}\right]\right\}^{1 / 2}$ 


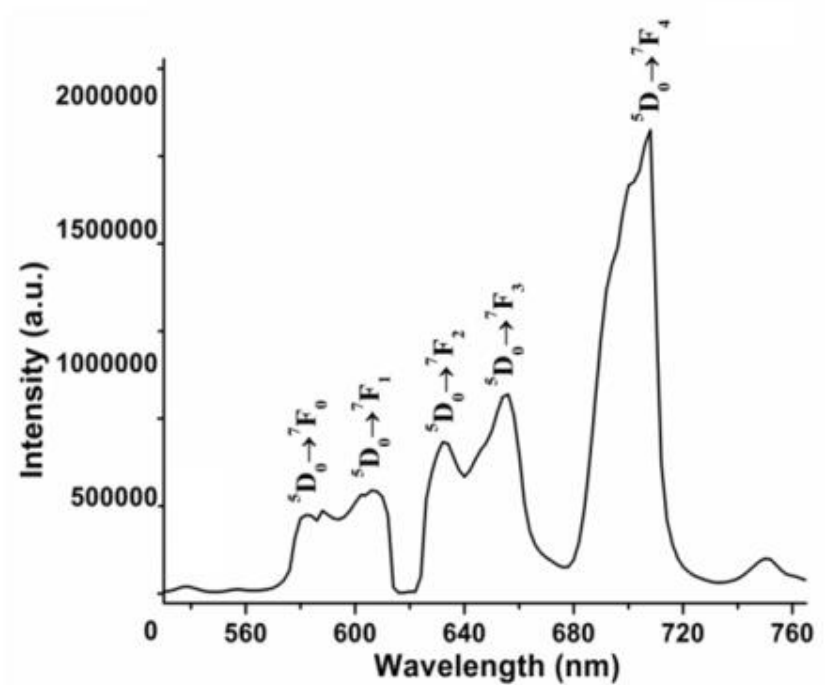

Figure 9. The photoluminescence spectrum of the complex Eu (2a), excitation at $460 \mathrm{~nm}$.

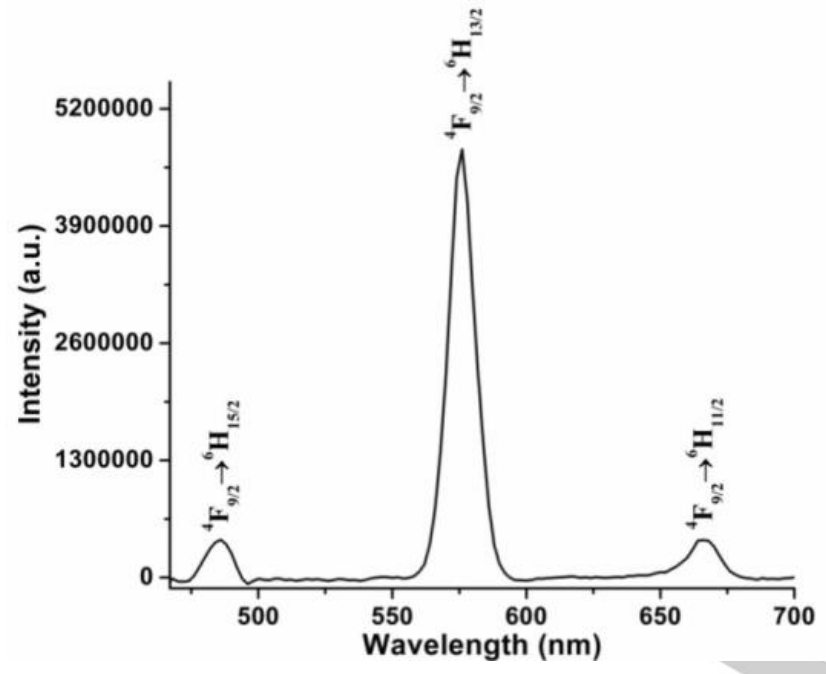

Figure 10. The photoluminescence spectrum of the complex Dy (5a), excitation at $370 \mathrm{~nm}$.

${ }^{4} \mathrm{~F}_{9 / 2} \rightarrow{ }^{6} \mathrm{H}_{13 / 2}$ and ${ }^{4} \mathrm{~F}_{9 / 2} \rightarrow{ }^{6} \mathrm{H}_{11 / 2}$ respectively (Figure 10). The transition corresponding to ${ }^{4} \mathrm{~F}_{9 / 2} \rightarrow{ }^{6} \mathrm{H}_{13 / 2}$ at $575 \mathrm{~nm}$ is related to the electric dipole environment of the $\mathrm{Dy}^{3+}$ ion. It has the highest intensity and is responsible for the yellow emission of the complex $5 \mathbf{a}^{[53,54]}$

\section{Experimental method for catalytic oxidation of thioethers by catalyst $\left\{\mathrm{Dy}_{8} \mathrm{Si}_{4} \mathrm{~W}_{40}\right\}$}

The catalytic oxidation reactions of thioethers was performed in $25 \mathrm{~mL}$ round bottom flask connected to a refluxing condenser under magnetic stirring at room temperature which was heated $\left(50^{\circ} \mathrm{C}\right)$. The desired amount of the catalyst was added into the flask, along with $1 \mathrm{~mL}$ of acetonitrile solution containing thioether and oxidant. The reaction vessel was sealed and stirred into a thermostated oil bath. Reaction progress was monitored by TLC and gas chromatography. After the reaction, the vessel was cooled to room temperature and extracted with ethyl acetate for GC analysis. The thioether oxidation products (sulfoxide and sulfone) were identified with GC-MS and quantified using gas chromatography with internal standard techniques.

\section{Thermogravimetric Analysis}

The thermogravimetric analysis (TGA) of all the complexes 1a-10a were performed in the range of $30-400{ }^{\circ} \mathrm{C}$ under inert condition $\left(\mathrm{N}_{2}\right.$ gas) at a heating rate of nitrogen gas of $5{ }^{\circ} \mathrm{C} / \mathrm{min}$. The TGA curves of the complexes 1a-10a show a single step weight loss of 7.5, 7.9, 7.5, 7.6, 8.8, $7.2,7.5,7.3,7.5,7.6 \%$ respectively, which are attributed to the loss of both lattice and coordinated water molecules (Figure S11).

\section{Powder X-ray Diffraction}

The X-ray powder diffraction patterns have been obtained for all the nanoclusters 1a-10a which has been shown in figure S14. It has been observed that powder patterns for all the complexes perfectly matches suggesting that all ten synthesized complexes are isostructural in nature. We have also compared the powder pattern of the complex with the simulated pattern obtained from single crystal X-ray diffraction (Figure S15). Both the patterns were almost similar with slight shifting in peaks which we believe might be due to the change in crystalline material to amorphous material while drying and pressing. [55]

\section{Acknowledgements}

F. H. thanks University of Delhi and SERB-DST project $E M R / 2016 / 002812$ for the financial support. We also thank University Science Instrumentation Centre (USIC) for the instrumentation facilities and IIT Bombay for ICP-AES. I. K. and V. D. thank CSIR for fellowship. A.-L. T., I.-M.M. and P.d.O. thank the CNRS and the University Paris-Saclay for financial support.

Keywords: Polyoxometalates - Lanthanide - Catalysis • Photoluminescence $\cdot$ Electrochemistry

[1] a) M. T. Pope in Heteropoly and Isopoly Oxometalates, Springer-Verlag, Berlin, 1983; b) M. T. Pope, A. Müller, Angew. Chem. 1991, 103, 56 Angew. Chem. Int. Ed. 1991, 30, 34.

[2] a) M. K. Saini, R. Gupta, S. Parbhakar, S. Singh, F. Hussain, RSC Adv 2014, 4, 38446; b) M. K. Saini, R. Gupta, S. Parbhakar, A. K. Mishra, R. Mathura, F. Hussain, RSC Adv. 2014, 4, 25357; c) F. Hussain, M. K. Saini, R. Gupta, S. Singh, Current Catalysis 2016, 5, 66.

[3] J. M. Sumliner, H. Lv, J. Fielden, Y. V. Geletii, C. L. Hill, Eur. J. Inorg. Chem. 2014, 2014, 635.

[4] J. T. Rhule, C. L. Hill, D. A. Judd, R. F. Schinazi, Chem. Rev. 1998, 98, 327.

[5] P. Lei, C. Chen, J. Yang, W. Ma, J. Zhao, Li. Zang, Environ. Sci. Technol. 2005, 39, 8466.

[6] a) R. Gupta, F. Hussain, J. N. Behera, A. M. Bossoh, I. M. Mbomekallé, P. D. Oliveira, RSC Adv. 2015, 5, 99754; b) R. Gupta, F. Hussain, M. Sadakane, C. Kato, K. Inoue, S. Nishihara, Inorg. Chem. 2016, 55, 8292; c) F. Hussain, R. W. Gable, M. Speldrich, P. Kögerler, C. Boskovic, Chem. Commun. 2009, 328.

[7] R. Gupta, M. K. Saini, F. Doungmene, P. D. Oliveira, F. Hussain, Dalton Trans. 2014, 43, 8290.

[8] R. Gupta, I. Khan, F. Hussain, A. M. Bossoch, I. M. Mbomekallé, P. D. Oliveira, M. Sadakane, C. Kato, K. Ichihashi, K. Inoue, S. Nishihara, Inorg. Chem. 2017, 56, 8759.

[9] R. D. Peacock, T. J. R. Weakley, J. Chem. Soc. A 1971, 1836.

[10] K. Wassermann, M. H. Dickman, M. T. Pope, Angew. Chem. 1997, 109 1513; Angew. Chem. Int. Ed. 1997, 36, 1445.

[11] a) L. Qu, Z. Niu, J. Liu, Y. Chen, B. Zhao, J. Peng, Gaodeng Xuexiao Huaxue Xuebao 1991, 12, 1434; b) Z. Niu, L. Qu, Y. Chen, J. Peng, J. Liu, Yingyong Huaxue 1992, 9, 46.

[12] P. Mialane, L. Lisnard, A. Mallard, J. Marrot, E. Antic Fidancev, P. Aschehoug, D. Vivien, F. Secheresse, Inorg Chem. 2003, 42, 2102. 
[13] G. L. Xuc, J. Vaissermann, P. Gouzerh, J. Cluster Sci. 2002, 13, 409.

[14] J. Y. Niu, J. W. Zhao, J. P. Wang, Inorg. Chem. Commun. 2004, 7, 876.

[15] J. P. Wang, J. W. Zhao, X. Y. Duan, J. Y. Niu, Cryst. Growth Des. 2006, 6, 507.

[16] B. Bassil, M. Dickman, I. Römer, B. Kammer, U. Kortz, Angew. Chem. 2007, 119, 6089; Angew. Chem. Int. Ed. 2007, 46, 6192.

[17] L. B. Ni, B. Spingler, S. Weyeneth, G. R. Patzke, Eur. J. Inorg. Chem. 2013, 2013, 1681.

[18] R. Khoshnavazi, E. Naseri, S. Tayamon, A. Ghiasi-Moaser, Polyhedron 2011, 30, 381.

[19] R. Khoshnavazi, R. Sadeghi, L. Bahrami, Polyhedron 2008, 27, 1855.

[20] R. Khoshnavazi, S. Gholamyan, J. Coord. Chem. 2010, 63, 3365.

[21] R. C. Howell, F. G. Perez, W. D. Horrocks, S. Jain, A. L. Rheingold, L. C. Francesconi, Angew. Chem. 2001, 113, 4155; Angew. Chem. Int. Ed. 2001, 40, 4031.

[22] R. Khoshnavazi, L. Bahrami, H. Davoodi, Inorg. Chim. Acta 2012, 382, 158.

[23] R. Gupta, M. K. Saini, F. Hussain, Eur. J. Inorg. Chem. 2014, 2014 , 6031.

[24] I. Khan, R. Kaushik, R. K. Tiwari, I. Mbomekallé, P. D. Oliveira, T. Matono, H. E. Ooyama, M. Sadakane, F. Hussain, ChemistrySelect 2019, 4, 12668.

[25] J.-X. Li, Z.-X. Du, L.-Y. Xiong, L.-L. Fu, W.-B. Bo, Journal of Solid State Chemistry 2021, 293, 121799.

[26] J.-X. Li, Z.-X. Du, Q.-Y.Pan, L.-L. Zhang, D.-L. Liu, Inorg. Chim. Acta 2020, 509, 119677.

[27] S. Li, P. Luo, H. Wu, C. Wei, Y. Hu, G. Qiu. ChemCatChem 2019, 11, 2978.

[28] S. Li, Q. Mo, X. Lai, Y. Chen, C. Lin, Y. Lu, B. Liao, Journal of Materials Research 2019, 34, 3220.

[29] I. D. Brown, D. Altermatt, Acta Crystallogr. Sect. B 1985, 41, 244.

[30] I. Fernandez, N. Khair, Chem. Rev. 2003, 103, 3651.

[31] J. K. Lu, X. Y. Ma, V. Singh, Y. J. Zhang, P. T. Ma, C. Zhang, J. Y. Niu, J. P. Wang, Dalton Trans. 2018, 47, 5279.

[32] S.S. Wang, G.Y. Yang, Chem. Rev. 2015, 115, 4893

[33] S. Vincent, C. Lion, M. Hedayatullah, A. Challier, G. Delmas, G. Magnaud, Phosphorus, Sulfur, and Silicon and the Related Elements 1994, 92, 189

[34] L. Huang, S.S. Wang, J.W. Zhao, L. Cheng, G.Y. Yang, J. Am. Chem. Soc. 2014, 136, 7637.

[35] Y. L. Wang, Z. Zhang, H.L. Li, X.Y. Li, G.Y. Yang, Eur. J. Inorg. Chem. 2019, 2019, 417.

[36] B. Keita, L. Nadjo, J. Electroanal. Chem. Interf. Electrochem. 1987, 227, 265.

[37] B. Keita, L. Nadjo, J. P. Haeussler, J. Electroanal. Chem. Interf. Electrochem. 1987, 230, 85.

[38] R. Contant, G. Herve, Rev. Inorg. Chem. 2002, 22, 63.

[39] L. Parent, P. D. Oliveira, A. L. Teillout, A. Dolbecq, M. Haouas, E. Cadot, I. M. Mbomekallé, Inorganics 2015, 3, 341.

[40] B. Keita, L. Nadjo, Electrochemistry of Isopoly and Heteropoly Oxometalates, in Encyclopedia of Electrochemistry, 2007, 7, 607.

[41] A. Tézé, G. Hervé, R. G. Finke, D. K. Lyon, Inorg. Synth. 1990, 27, 85.

[42] Xcalibur CCD System, Oxford Diffraction Ltd., Abingdon, Oxfordshire, England, 2007.

[43] CrysAlis Pro software system, Version 171.32, Oxford Diffraction Ltd. Oxford, UK, 2007.

[44] SCALE3 ABSPACK; CrysAlisPro, Version 1.171.36.32, Oxford Diffraction Ltd., Oxford, UK, 2013.

[45] a) G. M. Sheldrick, Acta Crystallogr. Sect. A: Found. Crystallogr. 2008 64, 112; b) G. M. Sheldrick, Acta Crystallogr. Sect. C: Struct. Chem. 2015, 71, 3.

[46] L. Yang, X. Xu, L. Hao, X. Yang, J. Tang, R. Xie, Opt. Mater. 2011, 33, 1695.

[47] X. Y. Zhao, S. X. Liu, Y. H. Ren, J. F. Cao, R. G. Cao, K. Z. Shao, J. Solid State Chem. 2008, 181, 2488.

[48] I. Creaser, M. C. Heckel, R. J. Neitz, M. T. Pope, Inorg. Chem. 1993 32, 1573.
[49] a) T. Yamase, H. Naruke, J. Chem. Soc., Dalton Trans. 1991, 285292 b) R. Ballardini, E. Chiorboli, V. Balzani, Inorg. Chim. Acta 1984, 95 323.

[50] F. S. Liu, Q. L. Liu, J. K. Liang, J. Luo, L. T. Yang, G. B. Song, Y. Zhang, L. X. Wang, J. N. Yao, G. H. Rao, J. Lumin. 2005, 111, 61.

[51] X. Wang, Y. Guo, Y. Li, C. Hu, N. Hu, Inorg. Chem. 2003, 42, 4135

[52] P. Mialane, L. Lisnard, A. Mallard, J. Marrot, E. A. Fidancev, P. Aschehoug, D. Vivien, F. Sécheresse, Inorg. Chem. 2003, 42, 2102.

[53] D. Shi, L. Chen, J. Zhao, Y. Wang, P. Ma, J. Niu, Inorg. Chem. Commun. 2011, 14, 324

[54] D. Zhang, C. Zhang, H. Chen, P. Ma, J. Wang, J. Niu, Inorg. Chim. Acta 2012, 391, 218.

[55] U. B. Mioč, M. R. Todorović, M. Davidović, P. Colomban, I. Holclajtner Antunović, Heteropoly compounds-From proton conductors to biomedical agents, Solid State lonics 176 (2005) 3005-3017. 


\section{Entry for the Table of Contents}

Insert graphic for Table of Contents here.

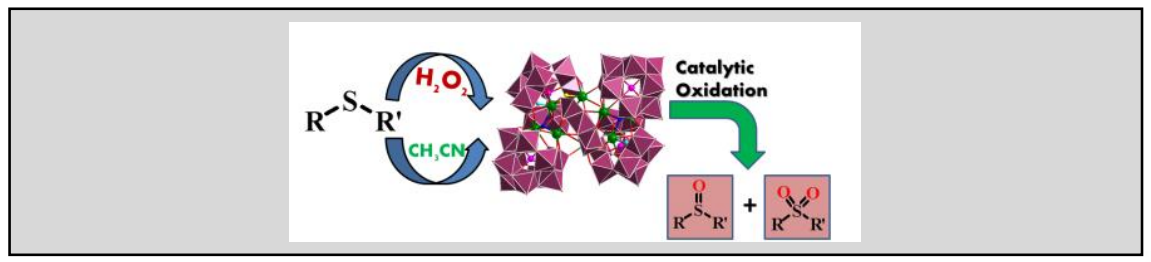

Insert text for Table of Contents here. A series of ten lanthanide-substituted $\left\{\mathrm{Ln}_{8} \mathrm{Si}_{4} \mathrm{~W}_{40}\right\}$ nanoclusters have been synthesized possessing a potential application in the field of Catalysis for the oxidation of thioethers. The complexes were characterized by various analytical techniques. Due to the redox properties of polyoxometalates, the electrochemistry of the synthesized nanoclusters were carried out. Furthermore, the photoluminescence properties were observed in three complexes.

Institute and/or researcher Twitter usernames: ((optional)) 